\title{
Yapı Bilgi Modellemesi Kullanımının Sürdürülebilir Yeşil Bina Projeleri Üzerine Etkileri
}

\author{
Aslı Pelin GÜRGÜN1 \\ Kerim KOÇ ${ }^{2}$ \\ Şenay ATABAY ${ }^{3}$
}

ÖZ

Doğal kaynakların hızla tükenişi ve kontrolsüz artan nüfus gibi sebepler her alanda olduğu gibi, inşaat sektöründe de sürdürülebilirliği zorunlu hale getirmiştir. Yapı Bilgi Modellemesi (YBM) uygulamaları bu amaca ulaşabilmek için, inşaat sektöründe son yıllarda önemli bir araç olarak kullanılmaktadır. Bu çalışmada iki ana bölümde YBM kullanımının sürdürülebilir yeşil bina projelerindeki avantajları incelenmiştir. İlk bölümde YBM kullanımının avantajları etkili oldukları proje aşamalarına göre değerlendirilmiştir. İkinci bölümde ise, bu aşamalarda YBM'nin inşaat projelerinin maliyet, süre, kapsam ve kalite kısıtlarına sağladığı katkılar irdelenmiştir. Analizler sonucunda, farklı disiplinler arası birlikte çalışabilirlik en önemli avantaj olarak saptanmış, bu avantajlarının proje aşamaları özelinde değişiklik gösterdiği tespit edilmiştir.

Anahtar Kelimeler: Yapı bilgi modellemesi, yapılarda sürdürülebilirlik, proje aşamaları, proje kisitları.

\section{ABSTRACT \\ Impacts of Using Building Information Modelling (BIM) in Sustainable Green Building Projects}

Rapid consumption of natural resources and uncontrolled increasing population made sustainability necessary in the construction industry, as in many other areas. Building Information Modeling (BIM) applications have been used as an important tool in the construction industry in recent years to achieve this goal. In this study, the advantages of using BIM in sustainable green building projects were investigated in two main parts. In the

\footnotetext{
Not: Bu yazı

- Yayın Kurulu'na 6 Nisan 2020 günü ulaşmıştır. 18 Ocak 2021 günü yayımlanmak üzere kabul edilmiştir.

- 31 Temmuz 2022 gününe kadar tartışmaya açıktır.

- https://doi.org/10.18400/tekderg.715574

1 Yıldız Teknik Üniversitesi, İnşaat Mühendisliği Bölümü, İstanbul - apelin@yildiz.edu.tr https://orcid.org/0000-0002-0026-4685

2 Yıldız Teknik Üniversitesi, İnşaat Mühendisliği Bölümü, İstanbul - kerimkoc@yildiz.edu.tr https://orcid.org/0000-0002-6865-804X

3 Yıldız Teknik Üniversitesi, İnşaat Mühendisliği Bölümü, İstanbul - satabay@yildiz.edu.tr https://orcid.org/0000-0002-0026-4685
} 
first part, the advantages of using BIM in sustainable projects according to effective project phases were examined. In the second part, contributions of BIM to cost, duration, scope and quality constraints were analyzed. The results indicate that interdisciplinary collaborating environment has been identified as the most important advantage and these advantages could vary according to project phases.

Keywords: Building information modelling, sustainable buildings, project phases, project constraints.

\section{GíRiş}

Dünyada son yıllarda hızla artan nüfus ile birlikte enerji talebi de hızlanarak artmaktadır. Bu talep nedeniyle artan enerji tüketimi sonucu ortaya çıkan çevresel faktörlerin baskısı ve enerji maliyetlerindeki artış, enerji kullanımıyla ilgili bazı faktörlerin dengelenmesi gerekliliğini ortaya koymaktadır. Yapılan tahminlere göre gelecekte de enerji ihtiyacı artarak devam edecektir. Enerji ihtiyacının büyük bir bölümü fosil yakıtlardan karşılanmaktadır. Ancak fosil yakıtların oluşum süreci kullanım hızından milyonlarca kat daha hızlı olduğundan, gelecekteki ihtiyacın karşılanamayacağı aşikârdır. Ayrıca, fosil yakıtların çevreye olumsuz etkisi de vahim boyutlara ulaşmaktadır. Günümüzde, zararlı gaz salımının azaltılması ve artan tüketim talebinin karşılanabilmesi için yenilenebilir enerji kaynaklarından faydalanılması zorunlu hale gelmiştir [1].

Enerji kaynaklarının yaklaşık \%40'ının, su kaynaklarının yaklaşık \%25'inin tüketiminden ve dünya sera gazı salımının yaklaşık üçte birinden sorumlu olması nedeniyle binalar sürdürülebilirlik açısından öncelikli olarak ele alınması gereken alanların başında yer almaktadır [2]. Ancak, sürdürülebilir yapılar inşa edilmeden önce mutlaka hedeflenen performans ölçütlerini sağlayıp sağlamadıkları kontrol edilmelidir. Aksi takdirde büyük maliyet ve zaman kayıpları meydana gelebilmektedir. Yapılar, sürdürülebilirlik açısından temel olarak enerji tüketimi, gün 1şı̆̆ 1 alımı, kendisi ve çevresi ile güneş ve gölge ilişkisi, ışınım kazanımı, rüzgâr kullanımı ve doğal havalandırma alanlarında analiz edilebilmektedir [3]. Bunların yanında etkili atık yönetimi, sürdürülebilir malzeme kullanımı ve malzeme geri dönüşümü sürdürülebilir yapılaşma için önerilen stratejiler arasındadır [4]. Örneğin, \%80, $\% 75$ ve $\% 65$ geri dönüşüm oranlarıyla Danimarka, Hollanda ve Japonya sürdürülebilir yapılaşmanın başarılı bir şekilde yürütüldüğü ülkeler arasında gösterilmektedir [5]. Ayrıca sürdürülebilir ya da genel olarak yeşil binalar kullanıcıların bina yaşam döngüsü boyunca maruz kalacağı iç hava kalitesini de artırmaktadır [6]. Geleneksel olarak bu gibi performans analizleri, fiziksel maketler ve laboratuvar koşullarında gerçekleştirilebilmekteyken, günümüzde ise binaların fiziksel gerçeklikte tüm alfasayısal (malzeme, maliyet, fiziksel çevre kontrolü) veri seti ile modellenmesi ve ardından performanslarının analiz edilmesi için sayısal teknikler mevcuttur. Bu sayısal çalışma biçimlerinden yapı bilgi modellemesi (YBM) yazılımları, binaların tüm grafik (geometri, biçim) ve alfasayısal verisinden oluşan bir 3B model meydana getirerek bu modelin proje katılımcıları tarafından yapının tüm yaşam döngüsü boyunca farklı şekillerde kullanımını sağlar [7], [8].

Bünyesinde barındırdığı birçok araç ve kolaylık ile YBM kullanımı inşaat sektörünün çevre üzerindeki negatif etkisinin azaltmayı ve daha sürdürülebilir bir gelişmenin yardımcısı olmayı hedeflemektedir [9], [10]. YBM'nin özellikle sürdürülebilir yeşil bina projelerinde kullanımı sürdürülebilirlik hedeflerine ulaşmak için çeşitli avantajlar sağlayacaktır. Wu ve Issa [11] YBM'nin sürdürülebilir yeşil bina projelerinde kullanımının inşaat firmaları için bir 
sinerji yaratacağına, ortaya atılan Yeşil YBM (Green BIM) kavramıyla birlikte işaret etmiştir. Ayrıca, atık azaltımı ve tasarım optimizasyonu gibi sürdürülebilir projelerde sürdürülebilirlik hedeflerine ulaşmak için geleneksel projelerden daha önemli hale gelen kavramların YBM kullanımı ile başarılı bir şekilde ele alınabileceği söylenebilir [12], [13]. Bu nedenle bu çalışmada, sürdürülebilir yeşil bina projelerinde YBM kullanımının proje aşamaları ve proje kısıtları hesaba katılarak sağladığı avantajların değerlendirilmesi hedeflenmektedir. Çalışmada ulaşıımaya çalışılan hedefler aşağıdaki gibi özetlenebilir:

- Proje aşamaları bazında sürdürülebilir yeşil bina projelerinde YBM kullanımının avantajlarının belirlenmesi ve değerlendirilmesi,

- YBM kullanımının hangi proje aşamalarına hangi proje kısıtı özelinde daha çok avantaj sağladığının belirlenmesi,

- Değişen katılımcı özelliğine göre sonuçların değişip değişmediğinin belirlenmesi,

- Sürdürülebilir yeşil bina projelerinde YBM kullanımının proje kısıtlarına sağladığı avantajların proje aşamaları özelinde değişip değişmediğinin belirlenmesi,

- Sürdürülebilir yeşil bina projelerinde YBM kullanımının proje aşamalarına sağladığı avantajların proje kısıtları özelinde değişip değişmediğinin belirlenmesi.

Bu çalışma genel olarak iki ana bölümde ele alınmıştır. Birinci bölümde YBM kullanımının sürdürülebilir proje üretimindeki avantajları, etkili oldukları proje aşamalarına (fizibilite, tasarım, ihale ve sözleşme, inşaat, ve işletme ve yönetim) göre belirlenmiş ve değerlendirilmiştir. İnşaat sektöründe çalışan, konu ile ilgili uzman kişilerle gerçekleştirilen anket çalışması ile sürdürülebilirlik ve YBM ilişsisi derinlemesine incelenmiş ve elde edilen sonuçlar analiz edilmiştir. İkinci bölümde ise bu aşamalarda YBM'nin inşaat projelerinin maliyet, süre, kapsam ve kalite kısıtlarına sağladığı katkılar irdelenmiştir. Her ne kadar YBM ve sürdürülebilirlik diğer birçok çalışmada incelenmiş ise de, proje aşamaları ve kısıtları bir arada hesaba katılarak, proje aşamaları ve kısıtları üzerinde sağlanan avantajların detaylı olarak analiz edildiği bir çalışmaya literatürde rastlanmamıştır. Özellikle sürdürülebilir yeşil bina projelerinde YBM kullanımının proje aşamaları bazında sağladığı faydaların proje kısıtlarına göre farklılaşıp farklılaşmadığı ve proje kısıtları bazında sağladığı faydaların proje aşamalarına göre farklılaşıp farklılaşmadığ 1 literatürde eksikliği saptanan bir araştırma konusudur. Bu çalışmanın literatürde karşılaşılan benzer çalışmalardan ayrıldığı nokta burasıdır. Hangi proje aşamasında YBM kullanılmasının ne gibi avantajlar sağlayacağı, aşamalar ve kısıtların birbirinden ayrı düşünülüp düşünülmediği yatırım kararı eşiğinde olan ve etkin proje yönetimi yapmak isteyen şirketler için büyük önem arz etmektedir. Her proje aşaması için YBM kullanacak kaynağı olmayan, bugüne kadar genellikle geleneksel yöntemlerle ilerleme kat etmeye çalışmış inşaat şirketleri, sürdürülebilirlik hedefleri kapsamında en uygun proje aşamalarını seçip bu aşamaları YBM kullanımı için birer başlangıç noktası olarak seçebilir. Bununla birlikte maliyet, süre, kapsam ve kalite genel olarak kabul görmüş proje kısıtları olarak karşımıza çıkmakta ve hangi proje aşamasında ne gibi kısıtların YBM kullanımı ile rahatlatılabileceğinin analizi, gelişen dünyada sürdürülebilirlik hedeflerine ulaşmak için büyük önem taşımaktadır. $\mathrm{Bu}$ şekilde sürdürülebilir yeşil bina projelerine ve bununla birlikte yeşil bina sertifikalarına, özellikle maliyet olmak üzere tüm proje kısıtları kapsamında önyargılı yaklaşan firmalar, çalışma bulguları ile firma hedeflerini birleştirerek sürdürülebilirlik zinciri içinde bir halka olma gayreti içine girebilirler. 


\section{YBM VE SÜRDÜRÜLEBİLİRLIKK}

YBM en temel tanımı ile bir yapının fiziksel ve fonksiyonel özelliklerinin dijital olarak tasvir edilmesidir [14], [15]. Başka bir tanıma göre ise, kavram proje öncesi, yapıyı oluşturan tüm elemanların özelliklerinin sayısal olarak inşa edilebildiği akıllı bir 3B sanal bina modelinin düşük risk ve yüksek değerle yapımını optimize etmek olarak belirtilmiştir [16]. YBM aynı zamanda bir yapının yaşam döngüsü süresince gerekli bilgi oluşturma ve yönetme süreçleri olarak da değerlendirilebilir [17]. İnşaat sektörüne radikal bir inovasyon getiren YBM teknolojisi, firmalara çeşitli alanlarda geniş firsatlar sunmaktadır [18]. Görselleştirme, koordinasyon, çeşitli senaryo analizleri yapabilme ve tedarik zinciri entegrasyonu YBM uygulamalarının önde gelen sebeplerinden olarak gösterilmektedir [19]. Sürdürülebilir binalar, yaşam döngüsünde çevre ve insan sağlığı üzerindeki kötü etkileri azaltmak, su, malzeme ve enerjiyi verimli kullanmak için; arazi seçimi, yerleşim, tasarım, taşıyıcı sistem, işletme, bakım ve yıkılma süreçlerinin etkili bir şekilde tasarlanması ile ortaya çıkan ürünler olarak gösterilebilir. Sürdürülebilirlik, insanların bugünkü ihtiyaçlarını, gelecek nesillerin kendi ihtiyaçlarını karşılamaları noktasında tehlike oluşturmadan karşılaması olarak tanımlanmaktadır [20]. Bu noktada, inşaat sektörünün çevre ve toplum üzerindeki yoğun etkisi de düşünüldüğünde [21], sürdürülebilir yeşil bina kavramı ve bu hususta yapılacak ilerlemeler büyük önem arz etmektedir. Bunun yanında, sürdürülebilirliğin taşınmaz değerini artıran özelliklerden biri olduğu yapılan araştırmalarla desteklenmiştir [22].

İnşaat sektöründe süregelen uygulamalar tasarım takımının işbirliği içinde çalışmasına engel olmakta, ve bunun sonucunda sıkça yanlış anlaşılmalara, inşaat sırasında pahalıya mal olan değişikliklere ya da etkin şekilde işlemeyen, fazla enerji tüketen, sürdürülebilir olmayan yapılara neden olmaktadır [2]. Sürdürülebilir yapı tasarımında YBM kullanımı, daha etkin proje geliştirme ve uygulama yönünde sürece birçok açıdan destek sağlama potansiyeline sahiptir. YBM bilgi entegrasyonu sağladığı için tasarım aşamasında sürdürülebilirlik faktörlerini hesaba katmayı mümkün kılmakta, verimliliğin artması ve inşaat atıklarının azalması noktasında projelere fayda sağlamaktadır [23], [24]. YBM tabanlı yazılımlar ile yapı modeli performansını ölçen simülasyon ortamları oluşturulabilmekte, sayısal ve grafik çıktılar elde edilebilmektedir. Böylece, yapı inşa edilmeden önce, sanal ortamda oluşturulan 3B model ile binanın performansı belirlenerek problemli alanlar tespit edilebilmekte ve bu problemlere erken aşamada çözüm üretilerek, maliyet, süre, kapsam ve kalite ile ilgili olan sorunlar önlenebilmektedir. Firmaları YBM kullanmaya iten en önemli faktörler arasında gösterilen görselleştirme ve koordinasyonun [25], özellikle sürdürülebilir yeşil bina projeleri için yüksek kalite ve minimum atık çözümlerine sağlayacağı katkılar düşünüldüğünde YBM özellikle bu tip projeler için bir gereklilik halini almaktadır [13].

Sürdürülebilir inşaat projeleri, sağlıklı bir yapılı çevre oluşturmak ve yönetmek için kaynak verimliliğini ve ekolojik kaygıları hesaba katarak gerçekleştirilen projelerdir [26]. Sürdürülebilir inşaat projelerinin uygulamaları ise çeşitli ülkeler tarafından geliştirilip kullanılan LEED (Leadership in Energy and Environmental Design) ve BREEAM (Building Research Establishment Environmental Assessment Method) gibi yeşil bina sertifikaları ile yaygınlık kazanmıştır [27]. Başka bir tanıma göre ise sürdürülebilir inşaat, yeşil bina sertifikası kazanmanın da proje hedefleri arasında olduğu inşaat projelerinin tasarım, inşaat ve işletme aşamalarındaki süreçlerini kapsar [28] ve ilgili projeler sürdürülebilir yeşil bina projeleri olarak adlandırılır. YBM kullanımı sürdürülebilir yeşil bina projelerine atık, karbon ayak izi, enerji ve su tüketimi, malzeme geri kullanımı ve yenilenebilir enerji kullanımı için 
çeşitli çözümler sunarak katkı sağlamaktadır [29]. Her ne kadar sürdürülebilirlik kavramı YBM literatüründeki çalışmaların merkezinde yer almasa da [30], YBM ve sürdürülebilirlik farklı birçok çalışmada birlikte kullanılmıştır. Örneğin, Reeves vd. [31] yeşil bina sertifikası olan ve olmayan iki binanın enerji performansını, aydınlatma, enerji kullanımı ve doğal havalandırma ekseninde yapı enerji modeli kullanarak karşılaştırmış ve sürdürülebilirlikle YBM'nin birlikte kullanılabileceğini göstermiş̧tir. Edwards vd. [32] YBM içerisindeki sürdürülebilirlik araçlarını bir yenileme projesi kapsamında inceleyerek sürdürülebilirlik gereksinimlerinin karşılanması için gerekli YBM araçlarını ilgili yeşil bina sertifika kategorilerine atamıştır. Jalaei vd. [33] tarafından geliştirilen modelde erken tasarım aşamasında sürdürülebilir yeşil bina sertifikaları için gerekli alınabilecek puanlar tahmin edilmeye çalışılmıştır. Carvalho vd. [34] bina sürdürülebilirlik değerlendirmesi için YBM'nin etkilerini analiz etmiş ve YBM'nin sadece sürdürülebilir yeşil binalara yönelik bir yaklaşım olmadığını fakat bu kapsamda büyük bir potansiyelinin olduğunu belirtmiş̧tir. Ölçer [35] iklim krizinde YBM'nin üstleneceği rolü araştırmış ve binanın karbon üretimini azaltmak için gerekli değişiklikler ve işletme aşamasında çevresel performansı yöneten analizler ile YBM'nin iklim sorunlarına olumlu katkı sağlayacağını ifade etmiştir. Chong vd. [36] tarafindan yapılan literatür taraması sonucunda sürdürülebilirlik kriterlerini belirlemek için yeni YBM araçlarına ihtiyaç duyulduğuna ulaşılmıştır. Olawumi ve Chan [37] tarafından gerçekleştirilen faktör analizi sonucunda ise YBM ve sürdürülebilirliğin ortak kullanılmasının avantajlarının beş ana faktörden oluştuğu tespit edilmiş̧ir. Bu faktörler özetle: i) verimlilik, ii) performans ve bilgi, iii) teknik, iv) finansal ve v) yasal avantajlardır.

Proje yaşam döngüsü özelinde YBM kullanımı ile ilgili literatürde birçok çalışmaya rastlamak mümkündür. Bu kapsamda, Bynum vd. [25] YBM kullanımını inşaat proje aşamaları özelinde incelemiş ve çalışmaya katılan uzmanlar YBM kullanımının optimum olduğu aşamaları şematik tasarım, tasarım öncesi ve tasarım olarak değerlendirmiştir. Oldukça az bir katılımcı ise YBM'nin inşaat dokümantasyon, inşaat öncesi ve işletme aşamalarında optimum fayda getireceğine işaret etmiş̧ir. Becerik-Gerber ve Kensek [38] YBM'nin kritik kullanım alanlarını incelemiş ve tüm proje aşamalarında tek bir YBM kullanımının YBM uygulamaları arasında en önemli yere sahip olduğuna değinmiştir. Lu vd. [39] yaptığı literatür taraması sonucunda YBM ve Yeşil binaları anlamak için üç temel yaklaşımın birlikte uygulanması gerektiğine dikkat çekmiştir: proje aşamaları, yeşil bina uygulamaları ile sahip olunan özellikler ve YBM özellikleri. Çalışmada ayrıca her bir proje aşamasında (Tasarım, inşaat, işletme, yenileme) YBM kullanımının sağlayacağı katkılar detaylıca verilmiştir. Marzouk ve Othman [40] bina sürdürülebilir sıhhi tesisat performansını YBM kullanarak modellemiş ve YBM kullanımını farklı proje aşamaları bazında sınıflandırmıştır. Li vd. [41] YBM kullanarak binalardaki inşaat aşamasında gerçekleşecek karbon üretimini incelemiş ve YBM'nin aynı amaç doğrultusunda işletme aşamasında da kullanılabileceğine dikkat çekmiştir. Zhou vd. [42] YBM kullanımının faydaları üzerine bir literatür taraması gerçekleştirmiş ve çoğu çalışmanın proje aşamaları özelinde bir ayrım yapmadan tüm aşamaları göz önünde bulundurduğuna işaret etmiştir. Yapılan literatür taramasında, inşaat projelerinde YBM ve sürdürülebilirlik konularını değişik açılardan inceleyen akademik çalışmalara rastlanmıştır. YBM ve sürdürülebilirlik kavram ve uygulamalarının bir arada ele alındığı çalışmalarda ise, bu çalışmanın odaklandığı şekilde proje aşamaları ve kısıtlarının değerlendirilmesi yapılmamıştır. 


\section{ARAŞTIRMA YÖNTEMI}

Bu çalışmada, daha önce değinildiği şekilde iki aşamalı olarak tasarlanan analizlerin yapılabilmesi amacıyla gerçekleştirilen anket çalışması için öncelikle kapsamlı bir literatür araştırması yapılmıştır. Scopus ve Google Scholar arama motorlarında "Yapı bilgi modelleme", "Sürdürülebilir inşaat", "Yeşil bina", "Avantaj", "Fayda" vb. anahtar sözcükleri kullanılarak arama yapılmış ve kapsamı bu çalışmanın kapsamına en yakın olduğu değerlendirilen 7 çalışma detaylıca incelenmiştir (Tablo 1). Bu araştırma sonunda belirlenen avantajlar alt alta sıralanmış ve etkili oldukları proje aşamalarının belirlenmesi için üç profesyonel ile pilot çalışma gerçekleştirilmiştir. Ardından sektörde tecrübeli uzmanlardan görüşlerini alabilmek amacıyla anket çalışmasına başlanmıştır. Sırasıyla önce YBM kullanımının sürdürülebilir yeşil bina projelerinde fizibilite, tasarım, ihale ve sözleşme, inşaat, ve işletme ve yönetim aşamalarında sağlayacağı avantajlar hakkında veri toplanmıştır. Daha sonra YBM kullanımının bu proje aşamalarında, maliyet, süre, kapsam ve kalite kısıtlarına olan etkileri ve farklılıkları incelenmiştir. Pilot çalışmasının ardından anketin ilk bölümünde 37 farklı avantaj belirlenmiştir (Tablo 1). Bunların etkili oldukları proje aşamalarındaki katkılarının ortaya çıkarılması amacıyla, katılımcılardan sürdürülebilir yeşil bina projelerinde YBM kullanmanın avantajlarını 1-5 ölçeğinde değerlendirmeleri istenmiştir. Çalışmanın akış şeması Şekil 1'de verilmiştir.

\section{Tablo 1 - Birinci bölüm anket sorularl}

\begin{tabular}{|c|c|c|c|c|c|c|c|c|}
\hline $\begin{array}{l}\text { Etkili } \\
\text { olduğu } \\
\text { proje } \\
\text { aşaması }\end{array}$ & Kod & Avantajlar & A & B & $\mathrm{C}$ & $\mathrm{D}$ & $\mathrm{E}$ & $\mathrm{F} G$ \\
\hline \multirow{5}{*}{ Fizibilite } & FZ1 & Proje süresinin azalması & $\boldsymbol{V}$ & $\boldsymbol{V}$ & $\checkmark$ & $\checkmark$ & - & $\checkmark v$ \\
\hline & FZ2 & Proje karlılığının artması & $\checkmark$ & - & - & - & - & $\checkmark-$ \\
\hline & FZ3 & 5D maliyet tahmini yapabilme & $\checkmark$ & $\boldsymbol{\nu}$ & - & $\boldsymbol{V}$ & $\boldsymbol{V}$ & $\checkmark-$ \\
\hline & FZ4 & Detay seviyesi belirleyebilme & - & - & - & $\boldsymbol{V}$ & $\boldsymbol{V}$ & -- \\
\hline & FZ5 & Yeni iş geliştirme kabiliyeti sağlaması & $\boldsymbol{V}$ & - & - & - & - & $\checkmark v$ \\
\hline \multirow{4}{*}{ Tasarım } & TA1 & Tasarım hatalarının erken önlenmesi & - & $\boldsymbol{\nu}$ & $\boldsymbol{\nu}$ & $\boldsymbol{\nu}$ & - & $\checkmark v$ \\
\hline & TA2 & Nesne tabanlı modelleme yapabilme & - & $\boldsymbol{V}$ & $\checkmark$ & - & - & $\checkmark-$ \\
\hline & TA3 & $\begin{array}{l}\text { Endüstri temel sinıfı (IFC) tabanlı dosya } \\
\text { transferi yapabilme }\end{array}$ & - & $\boldsymbol{\nu}$ & - & - & $\boldsymbol{V}$ & $\checkmark v$ \\
\hline & TA4 & Çakışma kontrolü & $\checkmark$ & $\boldsymbol{\nu}$ & $\checkmark$ & $\checkmark$ & - & $\checkmark-$ \\
\hline \multirow{3}{*}{ Tasarım } & TA6 & $\begin{array}{l}\text { Tasarımdaki değişikliğin tüm paftalara } \\
\text { yansıması }\end{array}$ & $\boldsymbol{V}$ & $\boldsymbol{V}$ & $\checkmark$ & $\checkmark$ & - & $\checkmark v$ \\
\hline & TA7 & 2D çizimlerin standartlaşması & - & $\boldsymbol{V}$ & - & - & $\boldsymbol{V}$ & $\checkmark-$ \\
\hline & TA8 & Sürdürülebilir bina tasarım kolaylığı & $\boldsymbol{v}$ & $\boldsymbol{V}$ & $\boldsymbol{v}$ & - & $\boldsymbol{V}$ & $\checkmark v$ \\
\hline
\end{tabular}


Tablo 1 - Birinci bölüm anket soruları (devam)

\begin{tabular}{|c|c|c|c|c|c|c|c|c|}
\hline $\begin{array}{l}\text { Etkili } \\
\text { olduğu } \\
\text { proje } \\
\text { aşaması }\end{array}$ & Kod & Avantajlar & A & B & $\mathrm{C}$ & $\mathrm{D}$ & $\mathrm{E}$ & $\mathrm{F} \mathrm{G}$ \\
\hline \multirow{5}{*}{$\begin{array}{l}\text { İhale ve } \\
\text { Sözleşme }\end{array}$} & İS1 & Maliyet azalması & $\boldsymbol{\sim}$ & $\boldsymbol{\sim}$ & $\boldsymbol{\sim}$ & $\boldsymbol{\nu}$ & - & $\checkmark v$ \\
\hline & İS2 & 6D sürdürülebilirlik analizlerini yapabilme & $\boldsymbol{\sim}$ & $\boldsymbol{\sim}$ & - & - & $\boldsymbol{\nu}$ & $\checkmark \checkmark$ \\
\hline & İS3 & Otomatik metraj alabilme & - & $\boldsymbol{\sim}$ & - & $\checkmark$ & - & $\checkmark-$ \\
\hline & İS4 & Erken tasarım doğrulaması & - & - & $\boldsymbol{\sim}$ & - & $\boldsymbol{\sim}$ & $-\boldsymbol{V}$ \\
\hline & İS5 & Dokümantasyon hatalarının azalması & $\boldsymbol{\sim}$ & $\checkmark$ & - & - & $\boldsymbol{\sim}$ & $\checkmark \checkmark$ \\
\hline \multirow{13}{*}{ İnşaat } & İN1 & Tasarım ve inşaat planlama entegrasyonu & $\boldsymbol{\sim}$ & $\boldsymbol{\sim}$ & $\boldsymbol{\sim}$ & $\boldsymbol{\nu}$ & $\checkmark$ & $\checkmark \checkmark$ \\
\hline & İN2 & Yalın inşaatı uygulama kolaylığı & $\checkmark$ & $\boldsymbol{\sim}$ & $\boldsymbol{\sim}$ & - & $\checkmark$ & $-\checkmark$ \\
\hline & İN3 & Tasarım ve inşaat tedarik entegrasyonu & - & - & - & - & $\boldsymbol{\sim}$ & $\checkmark v$ \\
\hline & İN4 & Yanlış imalatların azalması & - & $\boldsymbol{\sim}$ & - & $\boldsymbol{V}$ & - & $\checkmark-$ \\
\hline & İN5 & Farklı disiplinler arası birlikte çalışabilirlik & $\boldsymbol{\sim}$ & $\boldsymbol{\sim}$ & $\boldsymbol{\sim}$ & $\boldsymbol{\sim}$ & $\boldsymbol{\sim}$ & $\checkmark \checkmark$ \\
\hline & İN6 & 4D iş programı oluşturabilme & $\boldsymbol{\sim}$ & $\boldsymbol{\sim}$ & - & $\checkmark$ & - & $\checkmark \checkmark$ \\
\hline & İN7 & Tümleşik proje yönetimi & $\boldsymbol{\sim}$ & $\checkmark$ & $\boldsymbol{\sim}$ & $\boldsymbol{\nu}$ & $\boldsymbol{\sim}$ & $\checkmark-$ \\
\hline & İN8 & Modelin inşaat aşamasında kullanılabilmesi & $\boldsymbol{\sim}$ & $\boldsymbol{\sim}$ & $\boldsymbol{\sim}$ & - & $\boldsymbol{\sim}$ & $\checkmark v$ \\
\hline & İN9 & Çoklu tasarım projelerinde birlikte çalışabilirlik & - & $\boldsymbol{\sim}$ & - & - & - & $\checkmark \checkmark$ \\
\hline & İN10 & Her aşamada maliyet çıktısı alabilme & $\checkmark$ & $\boldsymbol{\sim}$ & - & - & - & $\checkmark \checkmark$ \\
\hline & İN11 & Anlaşmazlıkların azalması & $\checkmark$ & $\boldsymbol{\sim}$ & - & - & - & $\checkmark \checkmark$ \\
\hline & İN12 & İnsan kaynağının daha verimli kullanımı & - & $\boldsymbol{\sim}$ & - & $\boldsymbol{\sim}$ & $\boldsymbol{\sim}$ & $\checkmark v$ \\
\hline & İN13 & Değişikliklere hızlı adapte olabilme & $\boldsymbol{\sim}$ & $\boldsymbol{\nu}$ & $\boldsymbol{\sim}$ & $\boldsymbol{V}$ & - & $\boldsymbol{\nu}-$ \\
\hline \multirow{6}{*}{$\begin{array}{l}\text { İşletme ve } \\
\text { Yönetim }\end{array}$} & İY1 & Devir/teslim kolaylığ & $\boldsymbol{\nu}$ & $\boldsymbol{\nu}$ & - & - & - & -- \\
\hline & İY2 & $\begin{array}{l}\text { Özen isteyen aktivite ve bakım süresinin } \\
\text { azalması }\end{array}$ & $\boldsymbol{\nu}$ & - & - & - & - & $\checkmark-$ \\
\hline & İY3 & İşletme ve yönetim kolaylığı & $\boldsymbol{V}$ & $\checkmark$ & $\boldsymbol{\sim}$ & - & $\boldsymbol{\sim}$ & $\checkmark \checkmark$ \\
\hline & İY4 & 7D tesis \& bakım yönetimi yapabilme & $\boldsymbol{\sim}$ & $\boldsymbol{\sim}$ & - & - & $\boldsymbol{\sim}$ & $\checkmark \checkmark$ \\
\hline & İY5 & $\begin{array}{l}\text { Bina kullanım ömrü boyunca kolay bilgi } \\
\text { aktarımı }\end{array}$ & $\boldsymbol{\sim}$ & $\boldsymbol{v}$ & - & $\checkmark$ & - & $\checkmark v$ \\
\hline & İY6 & Müşteri memnuniyeti sağlaması & $\boldsymbol{\sim}$ & - & $\checkmark$ & - & - & $\checkmark-$ \\
\hline
\end{tabular}

Not: A: Bryde vd. [43], B: Kivits ve Furneax [44], C: Wong ve Fan [13], D: Luth vd. [45], E: Wu ve Issa [11], F: Ghaffarianhoseini vd. [46], G: Olawumi ve Chan [47]. 


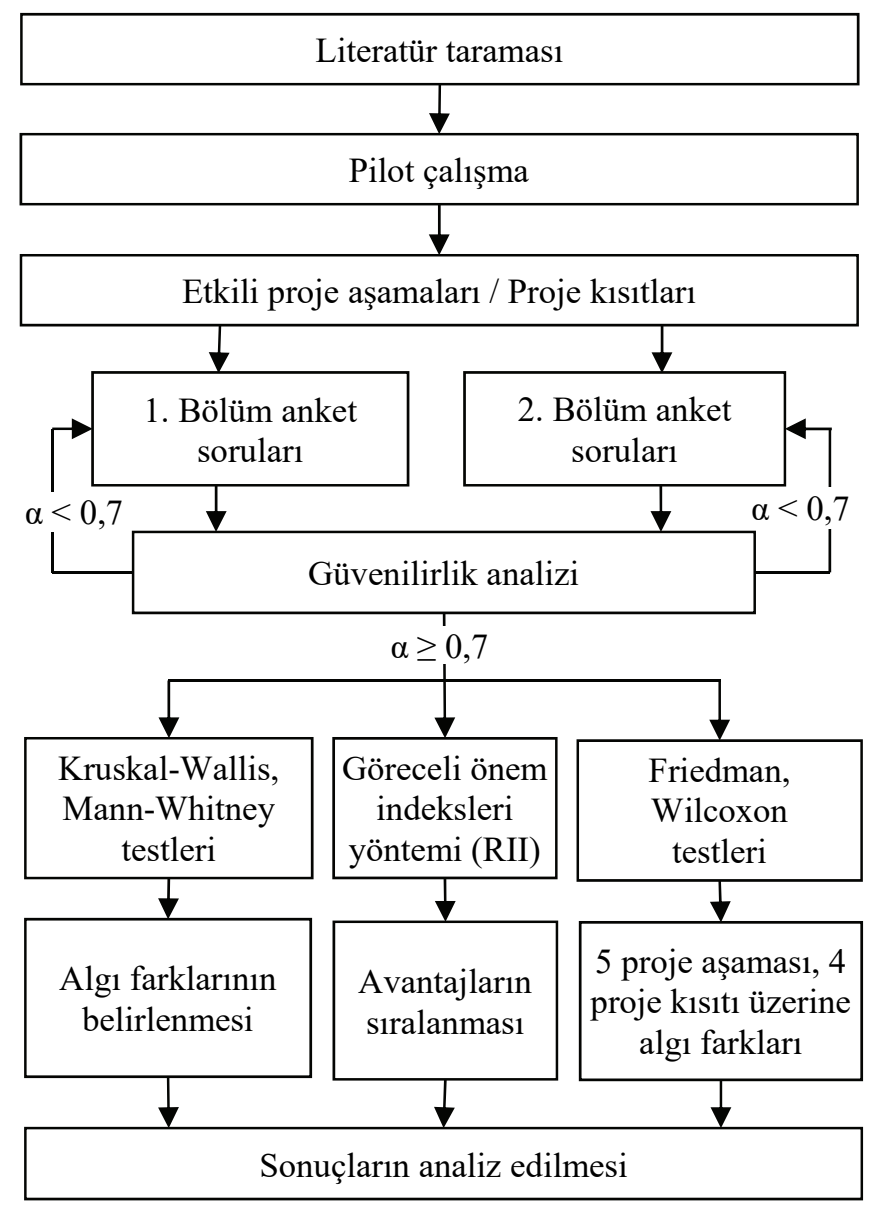

Şekil 1 - Çalışmanın akışşseması

YBM kullanımının avantajları incelenirken, projelerin belirli bir aşamasına odaklanmaktan ziyade, proje yaşam döngüsünün tamamına dikkat çekilmiştir. Bunun bir sebebi tüm proje aşamalarına odaklanarak YBM kullanımının tümleşik avantajlarını incelemek iken, diğer bir sebebi ise bu kapsamda literatürde yapılan çalışmaların eksikliğidir [45]. Bu bağlamda, Eadie vd. [48] tarafından yapılan proje yaşam döngüsü tanımı benimsenmiştir. $\mathrm{Bu}$ tanıma göre proje yaşam döngüsü; başlama, fizibilite, tasarım, inşaat, teslim etme, işletme ve bakım aşamalarının tamamını kapsamaktadır. Literatür geneline göre YBM kullanımı ise projelerin beş ana aşamasında yoğunlaşmaktadır. Bu aşamalar; fizibilite [49], [50], tasarım [49], [51], ihale ve sözleşme [49]-[51], inşaat [51], [52], ve işletme ve yönetim [52], [53] şeklinde siralanabilir. Bununla birlikte maliyet, süre, kapsam ve kalite, YBM kullanımının en önemli başarı kriterleri olarak gösterilmektedir [43]. Ayrıca, bir projenin başarısı, proje üçgeni (iron triangle) olarak da bilinen, merkezinde kalitenin yer aldığı maliyet, zaman ve kapsam kısıtlarına bağlı ölçülür [54]. Çalışmanın ikinci bölümünde YBM'nin yoğun olarak katkı 
sağladığı ve etkili olduğu proje aşamaları ve proje kısıtlarının bir arada düşünülmesi istenmiştir. Katılımcılara YBM'nin sürdürülebilir yeşil bina projelerinin beş farklı aşaması olan fizibilite, tasarım, ihale ve sözleşme, inşaat, ve işletme ve yönetim aşamalarına; dört farklı proje kısıtı olan maliyet, süre, kapsam ve kalite açısından avantajlarının etkileri sorulmuştur. Bu amaçla 20 sorgudan oluşan $5 \times 4$ boyutlarında bir matris hazırlanarak yanıtlar toplanmıştır.

Çalışmaya hem sürdürülebilirlik hem de YBM konularında bilgi sahibi olan 26 uzman katılmıştır. Çok sayıda katılımcıya ulaşmaktan ziyade doğru katılımcılara ulaşıp, özenli verilen yanıtların derlenmesi hedeflenmiştir. Simms ve Rogers [55]'in de ifade ettiği üzere katılımcıların çalışmalara istekli katılması ilgili konuyla ilgilendiklerini göstermekte ve böylece güvenilir sonuçlara ulaşmak için avantaj sağlamaktadır. Türk inşaat sektörünün bu alanlardaki uygulamaların kullanılmasında henüz gelişme aşamasında olduğu dikkate alındığında, katılımcıların bu konularda gerçekten fikir sahibi olmaları hedeflenmiştir. Anket çalışması yüz yüze görüşmelerle gerçekleştirilmiş olup, konunun ve ilgili sorunun doğru anlaşılıp anlaşılmadığı teyit edilerek ilerleme sağlanmıştır. Hem YBM hem de sürdürülebilir yeşil bina projelerinde çalışıyor ya da çalışmış olan uzmanlar, çeşitli sektör ve yeşil bina tecrübesine sahip olup bu konularda yetkin, çeşitli katılımcı özellikleri dikkate alınarak seçilmiştir. Böylece değişen katılımcı özelliklerine göre uzmanların görüşleri karşılaştırılabilecektir. Ankete katılan uzmanların demografik özellikleri Tablo 2'de gösterilmiştir. 1-3 yıl tecrübeli katılımcıların da çalışmaya dâhil edilmesinin sebebi ise, bu katılımcıların mezun oldukları okullarda sürdürülebilirlik ve YBM gibi bazı güncel konularda ders/seminer/toplantı gibi etkinliklere katılmış olmalarıdır. Bilindiği üzere YBM ve sürdürülebilirlik sürekli gelişen ve gelişmelere adapte olmanın zorlayıcı olabildiği süreçleri de kapsamaktadır. Bu çalışmadaki sektör tecrübesi için kullanılan aralık ve ilgili aralıktaki katılım yüzdeleri çeşitli sektör tecrübelerine bağlı çalışanların görüşlerini yansıtmak amacıyla belirlenmiş ve Budayan [56]'ın çalışmasındaki değerlerle benzerlikler göstermektedir.

26 uzmandan toplanan veriler SPSS 17.0 programı kullanılarak analiz edilmiştir. İlk olarak verilerin güvenilirliğini test etmek için güvenilirlik analizi (Reliability Analysis) yapılmıştır. Cronbach alpha testi faktörler arasındaki iç tutarlılık ve ortalama korelasyon katsayılarını hesaplayarak anketlerin güvenilirliğini belirleyen ve sıklıkla kullanılan bir yöntemdir [57]. Anketin güvenilir olarak değerlendirilebilmesi için hesaplanan alpha değerinin 0,7'den büyük çıkması gerekmektedir [58]. YBM'nin sürdürülebilir yeşil bina projelerindeki avantajlarını önem derecelerine göre sıralayabilmek için ise, göreceli önem indeksleri (Relative Importance Index: RII) yöntemi kullanılmıştır [59]. Sorgulanan faktörlerin göreceli önem indeksleri (RII), Eş. 1 ile hesaplanmaktadır;

$R I I=\frac{\sum w}{(A * N)}$

$\mathrm{Bu}$ denklemde $\mathrm{W}$ değeri faktörlere katılımcılar tarafından verilen ağırlıklardır $(1=$ çok önemsiz, 2 = önemsiz, 3 = orta derecede önemli, 4 = önemli, ve 5 = çok önemli); A = en yüksek ağırlık (bu çalışmada 5'tir); $\mathrm{N}=$ toplam katılımcı sayısıdır (bu çalışmada 26'dır). 
Tablo 2 - Katılımcıların demografik yapısı

\begin{tabular}{|c|c|c|c|}
\hline Profil & Kategoriler & $\begin{array}{l}\text { Katılımc1 } \\
\text { sayıları }\end{array}$ & Yüzdeler \\
\hline \multirow{4}{*}{ Katılımcıların sektör tecrübesi (yıl) } & $1-3$ & 6 & $23,1 \%$ \\
\hline & $4-9$ & 12 & $46,2 \%$ \\
\hline & $10-19$ & 5 & $19,2 \%$ \\
\hline & $\geq 20$ & 3 & $11,5 \%$ \\
\hline \multirow{4}{*}{$\begin{array}{l}\text { Katılımcıların yeşil bina (LEED, } \\
\text { BREEAM vs.) tecrübesi (yıl) }\end{array}$} & $1-3$ & 8 & $30.8 \%$ \\
\hline & $4-9$ & 11 & $42,3 \%$ \\
\hline & $10-19$ & 7 & $26,9 \%$ \\
\hline & $\geq 20$ & 0 & $0,0 \%$ \\
\hline \multirow{5}{*}{$\begin{array}{l}\text { Katılımcıların karar vermeye katılım } \\
\text { durumu }\end{array}$} & Hiçbir zaman & 0 & $0,0 \%$ \\
\hline & Nadir & 5 & $19,2 \%$ \\
\hline & Bazen & 11 & $42,3 \%$ \\
\hline & Sik sik & 8 & $30,8 \%$ \\
\hline & Her zaman & 2 & $7,7 \%$ \\
\hline \multirow{5}{*}{$\begin{array}{l}\text { Katılımcıların çalıştıkları proje } \\
\text { aşamaları }\end{array}$} & $\begin{array}{l}\text { Fizibilite } \\
\text { aşaması }\end{array}$ & 1 & $3.8 \%$ \\
\hline & Tasarım aşaması & 8 & $30.8 \%$ \\
\hline & $\begin{array}{l}\text { İhale ve } \\
\text { sözleşme } \\
\text { aşaması }\end{array}$ & 5 & $19.2 \%$ \\
\hline & İnşaat aşaması & 10 & $38.5 \%$ \\
\hline & $\begin{array}{l}\text { İşletme ve } \\
\text { yönetim aşaması }\end{array}$ & 2 & $7.7 \%$ \\
\hline \multirow{3}{*}{ Katılımcıların çalıştıkları pozisyon } & Mühendis & 10 & $38.5 \%$ \\
\hline & Mimar & 7 & $26.9 \%$ \\
\hline & Müdür/Yönetici & 9 & $34.6 \%$ \\
\hline
\end{tabular}

İstatistiksel analizlere devam edebilmek için kullanılacak testler genel olarak parametrik ve parametrik olmayan testler olmak üzere ikiye ayrılır. Varyans homojenliği ve normal dağılım gösteren veriler için parametrik testler uygulanabilir [60]. Bu çalışmadaki veri seti ise 30'dan küçük olduğu için, Shapiro-Wilk normallik testi yapılmıştır [61], [62]. Shapiro-Wilk normallik testi sonuçları, çeşitli istatistiksel özelliklerle birlikte Tablo 3 'te verilmiştir. Test sonuçlarına göre normal dağılım göstermeyen verilerin analizi için, literatürde de işaret edildiği gibi parametrik olmayan testler kullanılmıştır [61], [63]-[66]. Sorulara verilen yanıtların, katılımcıların sektör tecrübesi ve karar vermeye katılım seviyesine bağlı değişiklik 
gösterip göstermediğini tespit etmek için, parametrik testlerden tek yönlü varyans analizi’nin (One way ANOVA) parametrik olmayan karşılığı olan Kruskal-Wallis testi kullanılmıştır. İlgili profil yapısına göre anlamlı bir fark tespit edilen sorulardaki farklılıkların hangi gruplar arasında gerçekleştiğini tespit etmek için ise, her bir ikili grup için Mann-Whitney U testi uygulanmıştır [67].

Son olarak, birbiri ile ilişkili olan ve aynı katılımcıların oyladığ 1 ikiden çok faktör arasında önemli bir fark olup olmadığını araştıran Friedman testi [68], ikinci bölümdeki anket sorularını daha detaylı incelemek için çapraz olarak uygulanmıştır. Hem YBM'nin sürdürülebilir yeşil bina projelerindeki maliyet, süre, kapsam ve kalite kısıtları üzerine avantajlarının proje aşamalarına göre değişip değişmediğini, hem de YBM kullanımının sürdürülebilir yeşil bina projelerindeki her bir proje aşaması içinde bu kısıtlar üzerindeki avantajlarının önem derecelerinde bir farklılığın olup olmadığını araştırmak amaciyla Friedman testi uygulanmıştır. Bu testte her bir faktörün ortalama sıralaması; yanıtların sıklığı, standart sapma ve normal ortalama önem değerine bağlı olarak hesaplanır [69]. Friedman testi sonucunda bir farklılık tespit edilen gruplardaki farklılıkların kaynağını bulmak için ise Wilcoxon testi kullanılmıştır [68]. Bu çalışmada uygulanan tüm istatistiksel testlerde, literatürde de sıklıkla kullanılan 0,05 [70] ve 0,01 [68] anlamlılık seviyeleri (p) kullanılmıştır. 0,05 ve 0,01 anlamlılık seviyeleri sırasıyla, $\% 95$ ve $\% 99$ güven aralıklarını ifade etmektedir [71].

Tablo 3 - Shapiro-Wilk normallik testi sonuçları

\begin{tabular}{|c|c|c|c|c|c|c|c|}
\hline \multirow[b]{2}{*}{ Kod } & \multirow[b]{2}{*}{ Avantajlar } & \multicolumn{3}{|c|}{ Statistics } & \multicolumn{3}{|c|}{ Shapiro-Wilk } \\
\hline & & Mean & $\begin{array}{l}\text { Skewnes } \\
\mathrm{s}\end{array}$ & Kurtosis & $\begin{array}{l}\text { Statisti } \\
\quad \mathrm{c}\end{array}$ & df & Sig. \\
\hline FZ1 & Proje süresinin azalması & 4,308 & $-0,571$ & $-0,874$ & 0,777 & 26 & 0,000 \\
\hline FZ2 & Proje karlılığının artması & 3,808 & $-0,073$ & $-1,342$ & 0,833 & 26 & 0,001 \\
\hline FZ3 & 5D maliyet tahmini yapabilme & 4,269 & $-0,580$ & $-1,466$ & 0,722 & 26 & 0,000 \\
\hline FZ4 & Detay seviyesi belirleyebilme & 4,462 & $-0,807$ & $-0,272$ & 0,735 & 26 & 0,000 \\
\hline FZ5 & Yeni iş geliştirme kabiliyeti sağlaması & 3,846 & $-0,432$ & $-0,826$ & 0,863 & 26 & 0,003 \\
\hline TA1 & Tasarım hatalarının erken önlenmesi & 3,923 & $-0,743$ & $-0,786$ & 0,797 & 26 & 0,000 \\
\hline TA2 & Nesne tabanlı modelleme yapabilme & 3,962 & 0,078 & $-1,715$ & 0,777 & 26 & 0,000 \\
\hline TA3 & $\begin{array}{l}\text { Endüstri temel sınıfı tabanlı dosya } \\
\text { transferi yapabilme }\end{array}$ & 4,269 & $-0,969$ & 0,140 & 0,785 & 26 & 0,000 \\
\hline TA4 & Çakışma kontrolü & 4,077 & $-0,159$ & $-1,775$ & 0,760 & 26 & 0,000 \\
\hline TA5 & Tasarımın görsellerle desteklenmesi & 4,346 & $-0,778$ & $-1,310$ & 0,666 & 26 & 0,000 \\
\hline TA6 & $\begin{array}{l}\text { Tasarımdaki değişikliğin tüm paftalara } \\
\text { yansıması }\end{array}$ & 4,462 & $-1,083$ & $-0,531$ & 0,655 & 26 & 0,000 \\
\hline TA7 & $\begin{array}{l}\text { 2D çizimlerin ve kapsamın } \\
\text { standartlaşması }\end{array}$ & 4,115 & $-0,171$ & $-0,887$ & 0,807 & 26 & 0,000 \\
\hline TA8 & Sürdürülebilir bina tasarım kolaylığ 1 & 4,154 & $-0,251$ & $-1,004$ & 0,806 & 26 & 0,000 \\
\hline
\end{tabular}


Tablo 3 - Shapiro-Wilk normallik testi sonuçları (devam)

\begin{tabular}{|c|c|c|c|c|c|c|c|}
\hline \multirow{2}{*}{ Kod } & \multirow{2}{*}{ Avantajlar } & \multicolumn{3}{|c|}{ Statistics } & \multicolumn{3}{|c|}{ Shapiro-Wilk } \\
\hline & & Mean & Skewness & Kurtosis & Statistic & $\mathrm{df}$ & Sig. \\
\hline İS1 & Maliyet azalması & 4,192 & $-0,956$ & 1,603 & 0,785 & 26 & 0,000 \\
\hline İS2 & $\begin{array}{l}\text { 6D sürdürülebilirlik analizlerini } \\
\text { yapabilme }\end{array}$ & 4,154 & $-1,480$ & 3,096 & 0,780 & 26 & 0,000 \\
\hline İS3 & Otomatik metraj alabilme & 4,385 & $-1,509$ & 1,426 & 0,691 & 26 & 0,000 \\
\hline İS4 & Erken tasarım doğrulaması & 4,154 & $-0,287$ & $-1,279$ & 0,800 & 26 & 0,000 \\
\hline İS5 & Dokümantasyon hatalarının azalması & 3,923 & $-0,674$ & $-0,339$ & 0,843 & 26 & 0,001 \\
\hline İN1 & $\begin{array}{l}\text { Tasarım ve inşaat planlama } \\
\text { entegrasyonu }\end{array}$ & 4,423 & $-0,667$ & $-0,428$ & 0,749 & 26 & 0,000 \\
\hline İN2 & Yalın inşaatı uygulama kolaylığ & 4,077 & $-0,606$ & $-1,098$ & 0,782 & 26 & 0,000 \\
\hline İN3 & Tasarım ve inşaat tedarik entegrasyonu & 3,846 & $-0,452$ & $-1,362$ & 0,809 & 26 & 0,000 \\
\hline İN4 & Yanlış imalatların azalması & 4,154 & $-0,190$ & $-0,650$ & 0,797 & 26 & 0,000 \\
\hline İN5 & $\begin{array}{l}\text { Farklı disiplinler arası birlikte } \\
\text { çalışabilirlik }\end{array}$ & 4,731 & $-2,191$ & 3,840 & 0,504 & 26 & 0,000 \\
\hline İN6 & 4D iş programı oluşturabilme & 4,231 & $-0,486$ & $-1,504$ & 0,746 & 26 & 0,000 \\
\hline İN7 & Tümleşik proje yönetimi & 4,077 & $-1,001$ & 0,281 & 0,793 & 26 & 0,000 \\
\hline İN8 & $\begin{array}{l}\text { Modelin inşaat aşamasinda } \\
\text { kullanılabilmesi }\end{array}$ & 4,115 & $-0,242$ & $-1,811$ & 0,742 & 26 & 0,000 \\
\hline İN9 & $\begin{array}{l}\text { Çoklu tasarım projelerinde birlikte } \\
\text { çalışabilirlik }\end{array}$ & 4,615 & $-1,474$ & 1,190 & 0,636 & 26 & 0,000 \\
\hline İN10 & Her aşamada maliyet çıktısı alabilme & 3,923 & $-0,635$ & $-0,860$ & 0,826 & 26 & 0,000 \\
\hline İN11 & Anlaşmazlıkların azalması & 3,462 & 0,140 & $-0,096$ & 0,856 & 26 & 0,002 \\
\hline İN12 & İnsan kaynağının daha verimli kullanımı & 3,462 & $-0,513$ & $-0,028$ & 0,897 & 26 & 0,013 \\
\hline İN13 & Değişikliklere hızlı adapte olabilme & 4,115 & $-0,204$ & $-1,205$ & 0,808 & 26 & 0,000 \\
\hline İY1 & Devir/teslim kolaylığı & 4,038 & $-0,498$ & $-1,314$ & 0,774 & 26 & 0,000 \\
\hline İY2 & $\begin{array}{l}\text { Özen isteyen aktivite ve bakım süresinin } \\
\text { azalması }\end{array}$ & 4,154 & $-0,905$ & $-0,124$ & 0,801 & 26 & 0,000 \\
\hline İY3 & İşletme ve yönetim kolaylığ1 & 4,577 & $-1,286$ & 0,669 & 0,668 & 26 & 0,000 \\
\hline İY4 & 7D tesis \& bakım yönetimi yapabilme & 4,231 & $-1,886$ & 5,388 & 0,727 & 26 & 0,000 \\
\hline İY5 & $\begin{array}{l}\text { Bina kullanım ömrü boyunca kolay bilgi } \\
\text { aktarımı }\end{array}$ & 4,231 & 1,358 & $-0,177$ & 0,524 & 26 & 0,000 \\
\hline İY6 & Müşteri memnuniyeti sağlaması & 3,500 & 0,175 & $-0,626$ & 0,878 & 26 & 0,005 \\
\hline
\end{tabular}

\section{SONUÇLAR VE TARTIŞMALAR}

\subsection{Güvenilirlik Analizi ve Faktörlerin Göreceli Önem İndeksleri}

Analizlere ankete verilen yanıtlardaki güvenilirliğin kontrol edilmesiyle başlanmıştır. Cronbach alpha değeri 0 ile 1 arasında değişiklik göstermekte ve 1 değerine yakın olması 
verilerin daha yüksek iç tutarlılığa sahip olduğuna işaret etmektedir. Ayrıca verilerin güvenli kabul edilebilmesi için Cronbach alpha değerinin 0,7'den büyük olması gerekmektedir [58], [72].

Tablo 4 - İlk bölümdeki soruların anket sonuçları

\begin{tabular}{|c|c|c|c|c|}
\hline Kod & Avantajlar & $\mathrm{AO}$ & SS & RII \\
\hline İN5 & Farklı disiplinler arası birlikte çalışabilirlik & 4,731 & 0,871 & 0,946 \\
\hline İN9 & $\begin{array}{l}\text { Çoklu tasarım projelerinde birlikte } \\
\text { çalışabilirlik }\end{array}$ & 4,615 & 0,892 & 0,923 \\
\hline İY3 & İşletme ve yönetim kolaylığı & 4,577 & 1,076 & 0,915 \\
\hline TA6 & $\begin{array}{l}\text { Tasarımdaki değişikliğin tüm paftalara } \\
\text { yansıması }\end{array}$ & 4,462 & 0,811 & 0,892 \\
\hline FZ4 & Detay seviyesi belirleyebilme & 4,462 & 0,874 & 0,892 \\
\hline İN1 & Tasarım ve inşaat planlama entegrasyonu & 4,423 & 0,766 & 0,885 \\
\hline İS3 & Otomatik metraj alabilme & 4,385 & 0,604 & 0,877 \\
\hline TA5 & Tasarımın görsellerle desteklenmesi & 4,346 & 0,711 & 0,869 \\
\hline FZ1 & Proje süresinin azalması & 4,308 & 1,129 & 0,862 \\
\hline FZ3 & 5D maliyet tahmini yapabilme & 4,269 & 0,863 & 0,854 \\
\hline TA3 & $\begin{array}{l}\text { Endüstri temel sinıfı (IFC) tabanlı dosya } \\
\text { transferi yapabilme }\end{array}$ & 4,269 & 0,891 & 0,854 \\
\hline IYY5 & $\begin{array}{l}\text { Bina kullanım ömrü boyunca kolay bilgi } \\
\text { aktarımı }\end{array}$ & 4,231 & 0,643 & 0,846 \\
\hline İN6 & 4D iş programı oluşturabilme & 4,231 & 0,874 & 0,846 \\
\hline İY4 & 7D tesis \& bakım yönetimi yapabilme & 4,231 & 0,967 & 0,846 \\
\hline İS1 & Maliyet azalması & 4,192 & 0,643 & 0,838 \\
\hline İS4 & Erken tasarım doğrulaması & 4,154 & 0,637 & 0,831 \\
\hline TA8 & Sürdürülebilir bina tasarım kolaylığı & 4,154 & 0,784 & 0,831 \\
\hline İS2 & 6D sürdürülebilirlik analizlerini yapabilme & 4,154 & 0,908 & 0,831 \\
\hline İN4 & Yanlış imalatların azalması & 4,154 & 1,055 & 0,831 \\
\hline İY2 & $\begin{array}{l}\text { Özen isteyen aktivite ve bakım süresinin } \\
\text { azalması }\end{array}$ & 4,154 & 1,190 & 0,831 \\
\hline İN8 & Modelin inşaat aşamasında kullanılabilmesi & 4,115 & 0,647 & 0,823 \\
\hline İN13 & Değişikliklere hızlı adapte olabilme & 4,115 & 0,736 & 0,823 \\
\hline TA7 & 2D çizimlerin ve kapsamın standartlaşması & 4,115 & 1,093 & 0,823 \\
\hline İN7 & Tümleşik proje yönetimi & 4,077 & 0,941 & 0,815 \\
\hline TA4 & Çakışma kontrolü & 4,077 & 0,977 & 0,815 \\
\hline
\end{tabular}


Tablo 4 - İlk bölümdeki soruların anket sonuçları (devam)

\begin{tabular}{llccc}
\hline Kod & Avantajlar & AO & SS & RII \\
\hline IN2 & Yalın inşaatı uygulama kolaylığı & 4,077 & 1,021 & 0,815 \\
IYY1 & Devir/teslim kolaylığ1 & 4,038 & 0,430 & 0,808 \\
TA2 & Nesne tabanlı modelleme yapabilme & 3,962 & 0,909 & 0,792 \\
IN10 & Her aşamada maliyet çıtısı alabilme & 3,923 & 0,732 & 0,785 \\
TA1 & Tasarım hatalarının erken önlenmesi & 3,923 & 0,749 & 0,785 \\
İS5 & Dokümantasyon hatalarının azalması & 3,923 & 0,761 & 0,785 \\
INN3 & Tasarım ve inşaat tedarik entegrasyonu & 3,846 & 0,675 & 0,769 \\
FZ5 & Yeni iş geliştirme kabiliyeti sağlaması & 3,846 & 0,977 & 0,769 \\
FZ2 & Proje karlılığının artması & 3,808 & 0,967 & 0,762 \\
IYY6 & Müşteri memnuniyeti sağlaması & 3,500 & 1,008 & 0,700 \\
INN11 & Anlaşmazlıkların azalması & 3,462 & 0,906 & 0,692 \\
INN12 & İnsan kaynağının daha verimli kullanımı & 3,462 & 1,140 & 0,692 \\
\hline
\end{tabular}

Yapılan analiz sonucunda ilk bölümdeki 37 sorunun Cronbach alpha değeri 0,896 olarak hesaplanmış ve verilen yanıtlara göre anketin yüksek güvenilirlikte olduğu belirlenmiştir. [73]. İkinci bölümdeki soruların Cronbach alpha değeri ise 0,869 olarak hesaplanmıştır ve yine anketin yüksek güvenilirlikte olduğuna işaret etmektedir. Daha sonra Eş. 1 uygulanıp tüm bölümlerdeki soruların RII değerleri tespit edilmiştir. İlk bölümdeki soruların aritmetik ortalama (AO), standart sapma (SS) ve RII değerleri Tablo 4'de RII sıralamasına göre gösterilmiştir. Tablo 5 'te ise ikinci bölümdeki anket sonuçları matris formunda verilmiştir.

Tablo 4'deki sonuçlar, sürdürülebilir yeşil binalarda YBM kullanımının en büyük avantajlarının farklı disiplinler arası birlikte çalışabilirlik $(\mathrm{RII}=0,946$; inşaat aşaması), çoklu tasarım projelerinde birlikte çalışabilirlik $(\mathrm{RII}=0,923$; inşaat aşaması), işletme kolaylığı (RII $=0,915$; işletme ve yönetim aşaması), tasarımdaki değişikliğin tüm paftalara yansıması (RII $=0,892$; tasarım aşaması) ve detay seviyesi belirleyebilme (RII $=0,892$; fizibilite aşaması) olduğunu göstermektedir. Bu sonuçlar, İN5, INN9 ve TA6 avantajlarının ilk beş sıra içinde yer alması sebebiyle, katılımcıların birlikte çalışabilirliğe önem verdiklerini göstermektedir. Bulgular, Olawumi ve Chan [47]'ın elde ettiği sonuçlarla yakın benzerlikler göstermektedir. YBM ve sürdürülebilirliğgi beraber kullanmanın 36 avantajını sıraladıkları çalışmada, çoklu tasarım alternatiflerini kolaylaştırma, işletme ve bakım yönetimini iyileştirme, bilgi paylaşımını kolaylaştırma, ve entegre ortamda doğru tasarım görselleştirmesini sağlama etmenleri, yine 1-5 ölçeğinde 4,5 ortalamanın üzerinde puan almış, ve en önemli 5 fayda içerisinde yer almıştır. Bilgi paylaşımının kolaylaşması birlikte çalışabilirliğin, doğru tasarım görselleştirmesi ise tasarımdaki değişikliklerin tüm paftalara yansımasının birer sonucudur. Bunun yanında katılımcılar, insan kaynağının daha verimli kullanımı (RII = 0,692), anlaşmazlıkların azalması $(\mathrm{RII}=0,692)$ ve müşteri memnuniyeti sağlaması $(\mathrm{RII}=0,700)$ faktörlerini ise en alt sıralarda değerlendirilen avantajlar olarak belirlemiştir. Her ne kadar bu şekilde sıralanmış olsalar da, bu çalışmaya dâhil edilen bütün avantajların katılımcılar 
tarafından RII = 0,5 (1-5 ölçeğinde alınabilecek ortalama RII puanı) puanının üzerinde değerlendirilmeleri sebebiyle önemli avantajlar sağladıkları söylenebilir.

Tablo 5 - İkinci bölümdeki soruların anket sonuçları

\begin{tabular}{|c|c|c|c|c|c|c|c|c|c|c|c|c|}
\hline \multirow[b]{2}{*}{ Proje Aşamaları } & \multicolumn{3}{|c|}{ Maliyet (MA) } & \multicolumn{3}{|c|}{ Süre (SÜ) } & \multicolumn{3}{|c|}{ Kapsam (KA) } & \multicolumn{3}{|c|}{ Kalite (KL) } \\
\hline & $\mathrm{AO}$ & SS & RII & $\mathrm{AO}$ & SS & RII & $\mathrm{AO}$ & SS & RII & $\mathrm{AO}$ & SS & RII \\
\hline $\begin{array}{l}\text { Fizibilite aşamas1 } \\
\text { (FZ) }\end{array}$ & 3,23 & 1,34 & 0,646 & 3,62 & 1,33 & 0,723 & 4,08 & 0,98 & 0,815 & 3,31 & 1,01 & 0,662 \\
\hline $\begin{array}{l}\text { Tasarım aşaması } \\
\text { (TA) }\end{array}$ & 3,81 & 1,13 & 0,762 & 4,12 & 0,91 & 0,823 & 4,12 & 1,18 & 0,823 & 4,08 & 0,93 & 0,815 \\
\hline $\begin{array}{l}\text { İhale ve sözleşme } \\
\text { aşaması (İS) }\end{array}$ & 3,04 & 1,43 & 0,608 & 3,31 & 1,29 & 0,662 & 3,77 & 1,07 & 0,754 & 3,96 & 1,04 & 0,792 \\
\hline İnşaat aşaması (IN) & 4,00 & 0,69 & 0,800 & 4,27 & 0,72 & 0,854 & 3,62 & 0,64 & 0,723 & 3,77 & 1,27 & 0,754 \\
\hline $\begin{array}{l}\text { İşletme ve yönetim } \\
\text { aşaması (IY) }\end{array}$ & 4,00 & 1,02 & 0,800 & 3,96 & 0,96 & 0,792 & 3,62 & 0,94 & 0,723 & 3,12 & 1,40 & 0,623 \\
\hline
\end{tabular}

Tablo 5'deki veriler ışığında, YBM kullanımının sürdürülebilir yeşil bina projelerinin fizibilite aşamasında kapsam $(\mathrm{RII}=0,815)$, ihale ve sözleşme aşamasında kalite (RII = $0,792)$, tasarım aşamasında süre ve kapsam $(\mathrm{RII}=0,823)$, inşaat aşamasında süre $(\mathrm{RII}=$ $0,854)$, ve işletme ve yönetim aşamasında maliyet $(\mathrm{RII}=0,800)$ özelinde, diğer kısıtlardan daha fazla avantaj getireceği belirlenmiştir. Bu bulgular sürdürülebilir yeşil binaların YBM ile modellenmesi yapılırken, hangi proje aşaması için en fazla avantaj sağlayacağını gösterdiği için önemlidir. Örneğin, YBM kullanımının fizibilite, ve ihale ve sözleşme aşamalarında kalite ve kapsam kısıtlarına olumlu etkilerinin daha ön plana çıktığ1; inşaat, ve işletme ve yönetim aşamalarında ise proje maliyet ve süresine daha fazla katkıda bulunduğu değerlendirilmiştir. Bu bilgiler ışığında, kapsam muğlaklığının karmaşıklığı artırabileceği özel projelerde [74], ve kapsamın açıkça tanımlandığı durumlarda oldukça başarılı olabilen tasarla-yap (design-build) yöntemi ile teslim edilecek projelerde [75], özellikle fizibilite aşamasında YBM kullanımının oldukça avantajlı olacağı söylenebilir. Aksine, tasarla-ihale et-yap (design-bid-build) yöntemi ile teslim edilecek projelerde ise, doğası gereği sıralamalı gerçekleşen işlerden dolayı proje süresi ve maliyeti ciddi olarak artabilmekte [76], ve dolayısı ile özellikle inşaat ve tasarım aşamalarında YBM kullanımının artan süre ve maliyet baskısını azaltabileceği düşünülmektedir. İşletme ve yönetim aşamasında ise sıkı imtiyaz süresi içerisinde oluşabilecek zamansal problemler, öngörülemeyen sebeplerden ötürü ortaya çıkabilecek bakım ve onarım masrafları nedeniyle, özellikle kamu özel sektör işbirliği (Public-private partnership: PPP) projelerinde [77] YBM kullanımının avantajlı olacağı söylenebilir.

Elde edilen sonuçlar, ilgili literatürdeki çeşitli çalışmalar tarafından da desteklenmektedir. YBM'nin ihale ve sözleşme aşamasında kullanımı, istenen işlerin detay, özellik ve şartnamesini de içerdiği için kullanıcılara avantaj sağlamakta [78] ve bunların yapılacak işin kalitesi üzerine yoğun bir etkisi bulunmaktadır. Azhar [53]'ın yaptığı çalışmada ele aldığı bir projede; dokümantasyon, fizibilite ve operasyon aşamalarında YBM uygulaması, uygulamanın kendi maliyetinin üç katından daha fazla bir maliyet düşüşüne sebep olmuştur. 
Bununla birlikte YBM, birçok disiplin ve firmayı işbirliği içine sokması sebebiyle tasarım ve inşaat aşamalarında zaman ve kaynak tasarrufu yaparken, yapının daha verimli bir hale gelmesini sağlamakta [25], ve böylece sürdürülebilirliğe hizmet etmektedir.

\subsection{Sonuçların Katılımcı Özelliklerine Göre Değerlendirilmesi}

Sürdürülebilir yeşil bina projelerinde YBM kullanımının avantajlarının ankete katılan uzmanların çeşitli özelliklerine göre değişip değişmediğini saptamak için, parametrik olmayan veriler için kullanılan Kruskal-Wallis testi anketteki tüm sorulara uygulanmıştır. Test sonucunda önem derecesi anlamlılık değeri (Asymp. Sig.) 0,05'ten küçük çıkan sorguların sektör tecrübesine göre farklılık gösterdiği söylenebilir. Kruskal-Wallis testi sonucunda sektör tecrübesine göre değişiklik gösteren sorular ve anlamlılık değerleri Tablo 6'da verilmiştir.

Kruskal-Wallis testi, bir profil özelliğine göre hangi sorularda anlamlı bir fark olduğu cevabını verirken, hangi grupların diğerlerinden farklılaştığına yanıt vermemektedir. Anlamlı bir fark tespit edilen sorulardaki farklılıkların hangi gruplar arasında gerçekleştiğini belirlemek için, katılımcıların tecrübe sınıfına göre Mann-Whitney $U$ testi uygulanmıştır. Tablo 7'de, Kruskal-Wallis testi sonucunda anlamlı fark belirlenen soruların, Mann-Whitney $\mathrm{U}$ testi sonucunda elde edilen anlamlılık dereceleri gösterilmiştir.

Tablo 6 - Kruskal-Wallis test sonuçlarl

\begin{tabular}{lccc}
\hline Soru & Chi Square & Serbestlik derecesi & $p$ \\
\hline $\begin{array}{l}\text { Tasarım ve inşaat tedarik } \\
\text { entegrasyonu }\end{array}$ & 8,006 & 3 & 0,046 \\
$\begin{array}{l}\text { Tasarım hatalarının erken önlenmesi } \\
\text { Yeni iş geliştirme kabiliyeti }\end{array}$ & 8,506 & 3 & 0,037 \\
sağlaması & 7,846 & 3 & 0,049 \\
İhale ve sözleşme aşaması_Kalite & 11,151 & 3 & 0,011 \\
Tasarım aşaması_Maliyet & 10,257 & 3 & 0,017 \\
Tasarım aşaması_Kapsam & 8,794 & 3 & 0,032 \\
\hline
\end{tabular}

Bulgular, YBM kullanımının sürdürülebilir yeşil bina projelerinde tasarım ve inşaat tedarik entegrasyonu (INN3) ve tasarım hatalarının erken önlenmesi (TA1) faktörlerini, 1-3 yıl tecrübeli çalışanların, 4-9 yıl ve 20 ve üzeri yıl tecrübeli çalışanlara göre daha büyük bir avantaj olarak gördügünü göstermektedir. 20 yıl ve üzeri tecrübeye sahip katılımcılar YBM uygulamasının yeni iş geliştirme sağlaması (FZ5) faktörüne yeterince avantaj sağlamayacağını düşünürken, daha az tecrübeli katılımcılar, ilgili faktörün göreceli olarak daha fazla avantaj sağlayacağını düşünmektedir. Öte yandan, sürdürülebilir yeşil bina projelerinde ihale ve sözleşme aşamasında YBM kullanımının kalite boyutuna 1-3 yıl ve 20 yıl ve üzeri tecrübeye sahip katılımcılar, diğer katılımcılarla karşılaştırıldığında daha az katkı 
sağlayacağını düşünmektedir. Tasarım aşamasında YBM kullanımının inşaat maliyetine oldukça yüksek katkı sağlayacağını düşünen 10-19 yıl arası tecrübeye sahip katılımcılar ise, bu konuda 4-9 yıl ve 20 ve üzeri yıl tecrübeye sahip katılımcılardan ayrılmaktadır. Son olarak, yine tasarım aşamasında YBM kullanımının proje kapsamına oldukça katkı sağlayacağını düşünen 10-19 yıl tecrübeli uzmanlar, kendilerinden daha az ve daha çok tecrübeye sahip uzmanlardan ayrılmaktadır. Anket sonuçları, görece daha tecrübeli katılımcıların; tasarım, işletme ve yönetime bağlı faktörleri diğer katılımcılardan daha kritik gördüklerini göstermektedir. Görece daha az tecrübeli çalışanlar ise, inşaat aşamasındaki avantajlara daha çok odaklanmıştır. Bunun sebebi ise özellikle daha az tecrübeli uzmanların projelerin inşaat aşamasında yeşil bina sertifika gereksinimlerini yerine getirme bağlamında zorluk çekmeleri olabilir [6].

Tablo 7 - Mann-Whitney U test sonuçlarl

\begin{tabular}{lcccccc}
\hline Soru & $1-3 / 4-9$ & $\begin{array}{c}1-3 / 10- \\
19\end{array}$ & $1-3 />20$ & $\begin{array}{c}4-9 / 10- \\
19\end{array}$ & $4-9 />20$ & $\begin{array}{c}10- \\
19 />20\end{array}$ \\
\hline $\begin{array}{l}\text { Tasarım ve inşaat } \\
\text { tedarik entegrasyonu }\end{array}$ & $0,019^{*}$ & 0,168 & $0,023^{*}$ & 0,777 & 0,096 & 0,216 \\
$\begin{array}{l}\text { Tasarım hatalarının } \\
\text { erken önlenmesi }\end{array}$ & $0,021^{*}$ & 0,134 & $0,015^{*}$ & 0,579 & 0,151 & 0,156 \\
$\begin{array}{l}\text { Yeni iş geliştirme } \\
\text { kabiliyeti sağlamas1 }\end{array}$ & 0,921 & 0,317 & $0,017^{*}$ & 0,329 & $0,014^{*}$ & $0,04^{*}$ \\
$\begin{array}{l}\text { İhale ve sözleşme } \\
\text { aşaması_Kalite }\end{array}$ & $0,01^{*}$ & $0,013^{*}$ & 0,773 & 0,634 & 0,054 & $0,04^{*}$ \\
$\begin{array}{l}\text { Tasarım aşaması } \\
\text { Maliyet }\end{array}$ & 0,203 & 0,284 & 0,06 & $0,017^{*}$ & 0,061 & $0,016^{*}$ \\
$\begin{array}{l}\text { Tasarım aşaması } \\
\text { Kapsam }\end{array}$ & 0,613 & $0,032^{*}$ & 0,129 & 0,062 & 0,068 & $0,01^{*}$ \\
\hline
\end{tabular}

* Ortalamalar arasındaki farklar anlamlıdır $(p<0.05)$.

Değişen katılımcı tecrübelerine göre YBM kullanımının avantajlarının sıralaması Tablo 8'de verilmiştir. Elde edilen sonuçlara göre tüm grupların en önemli dört avantaj içinde yer verdiği ortak bir faktöre rastlanmamıştır. Bununla birlikte, farklı disiplinler arası birlikte çalışabilirlik (INN5) üç grup tarafından, çoklu tasarım projelerinde birlikte çalışabilirlik (INN9), işletme ve yönetim kolaylığı (İY3) ve detay seviyesi belirleyebilme (FZ4) ise ikişer grup tarafından en önemli dört avantajdan biri olarak gösterilmiştir. 10-19 yıl arası tecrübeye sahip katılımcılar ise, ilk dört avantaj konusundan diğer katılımcılardan en fazla ayrılan gruptur. $\mathrm{Bu}$ grup, proje süresinin azalması (FZ1) ve 4D iş programı oluşturabilme (İN6) avantajlarını, FZ4 ile birlikte en önemli avantaj olarak belirtmişlerdir. Tecrübeye bağlı değişen bu alg1, Awad ve Ghaziri [79]'nin tecrübe ve çalışmadan doğan kazanımları anlama olarak tanımladığı bilginin tecrübeye bağlı değişiklik göstermesi ile bağdaşmaktadır. 
Tablo 8 - Katılımcıların sektör tecrübesine göre YBM kullanımının avantaj sıralaması

\begin{tabular}{|c|c|c|c|c|c|}
\hline Kod & Avantajlar & $1-3$ y1l & $4-9$ y1l & $10-19$ y1l & $>20$ y1l \\
\hline FZ1 & Proje süresinin azalması & 22 & 7 & 1 & 16 \\
\hline FZ2 & Proje karlılı̆̆ının artması & 16 & 35 & 24 & 23 \\
\hline FZ3 & 5D maliyet tahmini yapabilme & 22 & 17 & 4 & 5 \\
\hline FZ4 & Detay seviyesi belirleyebilme & 10 & 2 & 1 & 16 \\
\hline FZ5 & Yeni iş geliştirme kabiliyeti sağlaması & 5 & 32 & 34 & 34 \\
\hline TA1 & Tasarım hatalarının erken önlenmesi & 2 & 32 & 30 & 34 \\
\hline TA2 & Nesne tabanlı modelleme yapabilme & 29 & 28 & 4 & 23 \\
\hline TA3 & $\begin{array}{l}\text { Endüstri temel sınıfi tabanlı dosya transferi } \\
\text { yapabilme }\end{array}$ & 27 & 7 & 4 & 10 \\
\hline TA4 & Çakışma kontrolü & 29 & 19 & 13 & 10 \\
\hline TA5 & Tasarımın görsellerle desteklenmesi & 2 & 13 & 13 & 23 \\
\hline TA6 & $\begin{array}{l}\text { Tasarımdaki değişikliğin tüm paftalara } \\
\text { yansıması }\end{array}$ & 7 & 7 & 13 & 1 \\
\hline TA7 & 2D çizimlerin standartlaşması & 10 & 25 & 24 & 16 \\
\hline TA8 & Sürdürülebilir bina tasarım kolaylığ & 10 & 28 & 30 & 1 \\
\hline İS1 & Maliyet azalması & 22 & 19 & 4 & 10 \\
\hline İS2 & 6D sürdürülebilirlik analizlerini yapabilme & 36 & 13 & 4 & 5 \\
\hline İS3 & Otomatik metraj alabilme & 16 & 7 & 4 & 5 \\
\hline İS4 & Erken tasarım doğrulaması & 10 & 25 & 13 & 16 \\
\hline İS5 & Dokümantasyon hatalarının azalması & 16 & 19 & 30 & 34 \\
\hline İN1 & Tasarım ve inşaat planlama entegrasyonu & 10 & 2 & 4 & 16 \\
\hline İN2 & Yalın inşaatı uygulama kolaylığı & 33 & 5 & 4 & 31 \\
\hline İN3 & Tasarım ve inşaat tedarik entegrasyonu & 22 & 25 & 13 & 37 \\
\hline İN4 & Yanlış imalatların azalması & 10 & 19 & 24 & 16 \\
\hline İN5 & Farklı disiplinler arası birlikte çalışabilirlik & 2 & 1 & 13 & 1 \\
\hline İN6 & 4D iş programı oluşturabilme & 27 & 17 & 1 & 10 \\
\hline İN7 & Tümleşik proje yönetimi & 33 & 13 & 13 & 16 \\
\hline İN8 & Modelin inşaat aşamasında kullanılabilmesi & 16 & 13 & 13 & 31 \\
\hline İN9 & Çoklu tasarım projelerinde birlikte çalışabilirlik & 1 & 2 & 13 & 5 \\
\hline İN10 & Her aşamada maliyet çıktısı alabilme & 22 & 28 & 24 & 28 \\
\hline İN11 & Anlaşmazlıkların azalması & 33 & 35 & 36 & 31 \\
\hline İN12 & İnsan kaynağının daha verimli kullanımı & 37 & 31 & 37 & 23 \\
\hline İN13 & Değişikliklere hızlı adapte olabilme & 7 & 19 & 24 & 28 \\
\hline İY1 & Devir/teslim kolaylığı & 7 & 32 & 13 & 23 \\
\hline İY2 & $\begin{array}{l}\text { Özen isteyen aktivite ve bakım süresinin } \\
\text { azalması }\end{array}$ & 16 & 19 & 24 & 10 \\
\hline IYY3 & İşletme ve yönetim kolaylığı & 5 & 5 & 4 & 1 \\
\hline İY4 & 7D tesis \& bakım yönetimi yapabilme & 29 & 7 & 13 & 5 \\
\hline İY5 & $\begin{array}{l}\text { Bina kullanım ömrü boyunca kolay bilgi } \\
\text { aktarımı }\end{array}$ & 16 & 7 & 30 & 10 \\
\hline İY6 & Müşteri memnuniyeti sağlaması & 29 & 37 & 34 & 28 \\
\hline
\end{tabular}


Anket sonuçlarının, ankete katılan uzmanların çalıştıkları projelerde karar vermeye katılım derecesi, katılımcı pozisyonu ve katılımcıların çalıştıkları proje aşamasına göre bir farklılık gösterip göstermediğini tespit etmek için yine Kruskal-Wallis testi uygulanmıştır. Fakat her iki bölümdeki toplam 57 sorunun anlamlılık değeri (Asymp. Sig.) 0,05 değerinden büyük çıktığı için, anket sonuçlarının, ilgili katılımcı özelliklerine göre değişmediği sonucu çıkarılmıştır. Karar vermeye katılım derecesine göre anket sonuçlarının bir farklılık göstermemesinin sebebi, katılımcıların kararlara katılım seviyelerinin, hangi düzeydeki kararlara katıldıkları noktasına işaret etmemeleri olarak düşünülebilir. Çalışılan proje aşamasına göre önemli bir değişiklik saptanmamasının sebebi ise, ilgili uzmanların diğer proje aşamalarında da tecrübeye sahip olmaları olarak gösterilebilir. Aynı yorum çalışılan pozisyon için de yapılabilir. Bu nedenle farklılığın kaynağının araştırıldığı bir sonraki aşama olan Mann-Whitney U testini uygulamaya gerek görülmemiştir. Fakat, istatistiksel olarak önemli bir fark tespit edilmese de ilgili uzmanların kendi çalıştıkları proje aşamaları üzerine YBM kullanımının avantajlarını daha önemli gördüğü sonucuna ulaşılmıştır. Ayrıca, mühendis olarak çalışanların inşaat aşamasındaki avantajları, mimar olarak çalışanların tasarım aşamasındaki avantajları, yönetici olarak çalışanların ise diğer aşamalardaki avantajları daha önemli gördükleri tespit edilmiştir.

\subsection{Proje Aşamalarının Maliyet, Süre, Kapsam ve Kalite Kısıtları Özelinde İrdelenmesi}

Anketin ikinci bölümünde katılımcılardan sürdürülebilir yeşil bina projelerinde YBM kullanımının proje aşamalarına göre maliyet, süre, kapsam ve kalite kısıtlarını dikkate alarak değerlendirmeleri istenmiştir. Bu değerlendirmelerin birbirinden farklılaşıp farklılaşmadığını irdelemek amacıyla Friedman testi uygulanmıştır. Parametrik olmayan Friedman testinin güçlü yanı, verinin kendisi yerine, verinin sıralamasını yaparak analiz etmesidir [80]. Bu yöntem benzer bir problem için katılımcıların zaman, maliyet ve kalite algılarını karşılaştırmak amacıyla Larsen vd. [68] tarafından uygulanmıştır. Friedman testi her bir aşamada 26 veri seti ile çalıştırılmıştır. Bu çalışmadaki veri seti miktarı Friedman testini uygulayabilmek için gerekli minimum veri seti olan 23 şartını sağlamaktadır [68].

Friedman testi sonuçlarına göre (Tablo 9) tasarım aşaması hariç diğer tüm proje aşamalarında, katılımcıların maliyet, süre, kapsam ve kalite kısıtları üzerine YBM kullanım avantajları hakkında farklı değerlendirmeler yaptığı belirlenmiştir. İnşaat aşamasındaki anlamlılık değeri 0,05 seviyesinde iken diğer aşamalarda 0,01 seviyesindedir. Farklılıkların daha ciddi olduğu noktalara odaklanmak amaciyla, 0,01 derecesinde farklılık tespit edilen proje aşamalarında hangi konularda farklılıkların gözlendiğini saptamak için Wilcoxon testi uygulanmıştır (Tablo 10). Tablodaki bulgular, ankete katılan uzmanların, sürdürülebilir yeşil bina projelerinin fizibilite aşamasında YBM kullanımının maliyet/süre, ve maliyet/kalite açısından avantajlarını farklı gördüklerini göstermektedir. Benzer şekilde ihale ve sözleşme aşamasında YBM kullanımının avantajları maliyet/kapsam ve maliyet/kalite özelinde, işletme aşamasındaki avantajları ise maliyet/kalite ve süre/kalite özelinde farklı düşünülmektedir. Bu farklılıklar bu çalışmada elde edilen önemli bulgulardan biridir. Çünkü Luong vd. [81]'nin toplam proje faydasını dayandırdı̆̆ düşünülebilmesi oldukça zordur. 
Tablo 9 - Proje aşamaları bazında Friedman testi sonuçları

\begin{tabular}{lcc}
\hline Proje Aşamaları & Chi-Square & $p$ değeri \\
\hline Fizibilite aşaması & 15,422 & $0,001^{\mathrm{a}}$ \\
Tasarım aşaması & 3,224 & 0,358 \\
İhale ve sözleşme aşaması & 15,433 & $0,001^{\mathrm{a}}$ \\
İnşaat aşaması & 7,892 & $0,048^{\mathrm{b}}$ \\
İşletme ve yönetim aşaması & 17,081 & $0,001^{\mathrm{a}}$ \\
\hline${ }^{\mathrm{a}} 0,01$ seviyesinde anlaml ${ }^{\mathrm{b}}{ }^{\mathrm{b}} 0,05$ seviyesinde anlamlı
\end{tabular}

Tablo 10 - Proje aşamaları bazında Wilcoxon testi sonuçları

\begin{tabular}{lccc}
\hline Proje aşamaları & İkili kombinasyon & Z değeri & $p$ değeri \\
\hline Fizibilite & Maliyet/Süre & $-2,887$ & $0,004^{*}$ \\
& Maliyet/Kapsam & $-3,531$ & $0,000^{*}$ \\
& Maliyet/Kalite & $-0,105$ & 0,917 \\
& Süre/Kapsam & $-2,389$ & 0,017 \\
& Süre/Kalite & $-0,89$ & 0,373 \\
& Kapsam/Kalite & $-2,443$ & 0,015 \\
\hline İhale ve sözleşme & Maliyet/Süre & $-1,252$ & 0,21 \\
& Maliyet/Kapsam & $-2,805$ & $0,005^{*}$ \\
& Maliyet/Kalite & $-2,704$ & $0,007 *$ \\
& Süre/Kapsam & $-2,288$ & 0,022 \\
& Süre/Kalite & $-2,048$ & 0,041 \\
& Kapsam/Kalite & $-0,738$ & 0,46 \\
\hline İşletme ve yönetim & Maliyet/Süre & $-0,369$ & 0,712 \\
& Maliyet/Kapsam & $-2,045$ & 0,041 \\
& Maliyet/Kalite & $-2,844$ & $0,004^{*}$ \\
& Süre/Kapsam & $-1,764$ & 0,078 \\
& Süre/Kalite & $-2,865$ & $0,004^{*}$ \\
& Kapsam/Kalite & $-1,938$ & 0,053 \\
\hline & & & \\
& &
\end{tabular}

*0,01 seviyesinde anlaml

Aynı analizler maliyet, süre, kapsam ve kalite bazında gerçekleştirilip, YBM uygulamasının sürdürülebilir yeşil bina projelerinde proje aşamasına göre farklılaşıp farklılaşmadığı analiz edilmiştir. Diğer bir deyişle, sürdürülebilir yeşil bina projelerinde YBM kullanımının maliyet, süre, kapsam ve kalite kısıtlarına sağladığı avantajların proje aşaması bazında 
değişip değişmediği analiz edilmiştir. Friedman ve Wilcoxon testlerinin sonuçları sırasıyla Tablo 11 ve Tablo 12'de gösterildiği gibidir.

Tablo 11 - Maliyet, süre, kapsam ve kalite kısıtları bazında Friedman testi sonuçları

\begin{tabular}{lcc}
\hline $\begin{array}{l}\text { YBM kullanımının } \\
\text { avantaj boyutları }\end{array}$ & Chi-Square & $p$ değeri \\
\hline Maliyet & 11,72 & $0,02^{\mathrm{b}}$ \\
Süre & 10,223 & $0,037^{\mathrm{b}}$ \\
Kapsam & 9,044 & 0,06 \\
Kalite & 19,902 & $0,001^{\mathrm{a}}$ \\
\hline${ }^{\mathrm{a}} 0,01$ seviyesinde anlaml1, ${ }^{\mathrm{b}} 0,05$ seviyesinde anlamlı
\end{tabular}

Tablo 12 - Kalite bazında Wilcoxon testi sonuçları

\begin{tabular}{lcc}
\hline Proje aşamaları ikili kombinasyonları & Z değeri & $p$ değeri \\
\hline Fizibilite/Tasarım & $-2,748$ & $0,006^{*}$ \\
Fizibilite/İhale ve sözleşme & $-2,31$ & 0,021 \\
Fizibilite/İnşaat & $-1,928$ & 0,054 \\
Fizibilite/İşletme ve yönetim & $-0,209$ & 0,834 \\
Tasarım/İhale ve sözleşme & $-0,728$ & 0,467 \\
Tasarım/İnşaat & $-1,17$ & 0,242 \\
Tasarım/İşletme ve yönetim & $-2,933$ & $0,003 *$ \\
İhale ve sözleşme/İnşaat & $-0,645$ & 0,519 \\
İhale ve sözleşme/İşletme ve yönetim & $-2,626$ & $0,009 *$ \\
İnşaat/İşletme ve yönetim & $-2,98$ & $0,003 *$ \\
\hline *0,01 seviyesinde anlamlı & &
\end{tabular}

Ankete katılan katılımcılar, sürdürülebilir yeşil bina projelerinde YBM kullanımının maliyet, süre, kapsam ve kalite kısıtları üzerine avantajlarından sadece kaliteyi proje süreçlerine göre 0,01 anlamlılık derecesinde değişiklik gösterir bulmuşlardır. $\mathrm{Bu}$ nedenle Tablo 11'de sonuçları verilen Wilcoxon testi sadece kalite özelinde gerçekleştirilmiştir. Bulgular, fizibilite/tasarım, ihale ve sözleşme/işletme ve yönetim, tasarım/işletme ve yönetim, ve inşaat/işletme ve yönetim aşamalarında YBM kullanımının kalite üzerine avantajlarının değişiklik gösterdiğine, diğer hiçbir ikili karşılaştırmada ise değişiklik göstermediğine işaret etmektedir. Test sonuçlarına göre, tasarım, ihale ve sözleşme, ve inşaat aşamalarında YBM kullanımının sürdürülebilir yeşil bina projelerinde kaliteye olan katkısının diğer aşamalardan yüksek olduğu ve bu farkın 0,01 seviyesinde anlamlı olduğu söylenebilir. 


\subsection{Sonuçların Türkiye Özelinde İrdelenmesi}

Dünyada ve Türkiye'de YBM ile ilgili çeşitli akademik çalışma ve uygulamalar gerçekleştirilmektedir. Bu çalışmadaki uzman havuzu Türkiye inşaat sektöründen seçildiği için, sonuçlar Türkiye özelinde değerlendirilebilir. Sonuçların çeşitli bölgelere göre karşılaştırılması açısından Olawumi ve Chan'ın [64] çalışması kullanılabilir. Bu çalışmaya göre, YBM'nin sürdürülebilir yeşil bina projelerindeki avantajları, akademisyenlerin, sektör çalışanlarının, dünyanın değişik bölgelerindeki uzmanların değerlendirmeleri göz önünde bulundurularak ayrı ayrı hesaplanmıştır. İlgili çalışmada bilgi paylaşımını kolaylaştırması akademisyen ve doğulu uzmanlar tarafından en önemli avantaj olarak saptanmışken, batılı uzmanlar ve sektör çalışanları proje kalite ve verimliliğini artırmasını, en önemli avantaj olarak göstermiştir. Bu çalışmada ise farklı disiplinler arası birlikte çalışabilirlik ve çoklu tasarım projelerinde birlikte çalışabilirlik en önemli avantaj olarak saptanmış ve ilgili çalışma ile karşılaştırıldığında Türkiye inşaat sektörü uzmanlarının dünya genelindeki akademisyenler ve doğulu uzmanlarla benzer fikirde olduğu görülmüştür. Olbina ve Elliot [82] YBM uygulamalarındaki faydaları ENR (Engineering News Record) listesinde ilk yüzde yer alan firmalarla gerçekleştirdiği anket çalışması ile farklı bina tipleri için analiz etmiştir. Çalışmada gerçekleştirilen faktör analizi sonucunda, YBM'nin takım çalışmasını ve işbirliğini artırması en etkili insan faktörleri olarak belirlenmiş, farklı tipte projeler için avantajların önemli ölçüde değişmediği tespit edilmiştir.

Türkiye özelinde düşünüldüğünde yapılan analizler sonucu öne çıkan bulgular daha çok proje aşamaları ve kısıtlarının birlikte değerlendirilmesi ile elde edilmiştir. Bu değerlendirmelere göre sürdürülebilir yeşil bina projeleri için YBM kullanımı fizibilite aşaması için kapsam kısıtına, ihale ve sözleşme aşaması için kalite kısıtına, tasarım aşaması için süre ve kapsam kısıtlarına, inşaat aşamasında süre kısıtına, ve işletme ve yönetim aşamasında maliyet kısıtına diğer kısıtlardan daha çok katkı sağlayacaktır. Sürdürülebilir malzeme üretiminde yaşanan sıkıntılar, endüstri temel sınıfı geliştirme zorlukları ve güncel standartlardaki eksiklikler, Türkiye'de sürdürülebilirlik ve YBM'nin entegre edilebilirliğini zorlayan başlıca sebeplerdendir [83]. Bunun yanında, Türkiye'de YBM'nin sürdürülebilir yeşil bina projelerinin her aşamasında kullanımını kısıtlayan en önemli etkenler arasında kalifiye çalışan bulma zorluğu ve bütçe problemleri de gösterilebilir [84]. Dolayısı ile özellikle maliyet kısıtına katkı sağlaması sebebiyle sürdürülebilir yeşil binaların işletme ve yönetim aşamalarında YBM kullanımının teşvik edilmesi büyük önem taşımaktadır. Fizibilite aşamasında kapsam kısıtına ve ihale ve sözleşme aşamasında kalite kısıtına sağladığı avantajlar hesaba katılığında, ilgili konularda yetkinliğe sahip teknik personel ve mühendis yetiştirmenin önemi ortaya çıkmaktadır. $\mathrm{Bu}$ kapsamda, çoğu üniversitenin inşaat mühendisliği bölümünde zorunlu ders kapsamında yer almayan YBM ve sürdürülebilirlik gibi konuların, zorunlu dersler kapsamına sokulması projelerin istenilen kalite ve kapsamda tamamlanması açısından önem taşımaktadır.

\section{SONUÇLAR}

İnşaat sektörünün çevreye, topluma ve ekonomiye olan ciddi etkileri düşünüldüğünde sürdürülebilir yapılaşmanın önemi daha da artmaktadır. İnşaat sektöründe sürdürülebilirliğe ulaşmak için kaynak kullanımını minimize etmek ve disiplinler arası ortak ve verimli bir çalışmaya ortam sağlamak gerekmektedir. YBM bu amaca ulaşabilmek için son yıllarda sık 
sık kullanılan sistemlerden biridir. $\mathrm{Bu}$ nedenle YBM farklı şirketler tarafindan değişik sürdürülebilirlik amaçları doğrultusunda kullanılabilir. Fakat literatüre bakıldığı zaman, her ne kadar YBM ve sürdürülebilirliğgin birlikte kullanımının avantajları birçok kez çalışılmış olsa da, etkili olduğu proje aşamaları ve proje kısıtlarının birlikte hesaba katıldığı herhangi bir çalışmaya rastlanmamıştır.

$\mathrm{Bu}$ kapsamda literatürde belirlenen eksiklikleri gidermek amacıyla bir anket çalışması düzenlenerek sektördeki uzmanlara ulaşmaya çalışılmıştır. Bunun için önce kapsamlı bir literatür taraması yapılmış ve YBM kullanımının sürdürülebilir yeşil bina projelerine sağlayabileceği avantajların, bu avantajların etkili olduğu proje aşamalarına (fizibilite, tasarım, ihale ve sözleşme, inşaat, ve işletme ve yönetim) etkileri araştırılmıştır. Ardından ikinci bölümde YBM'nin, bu aşamaların projelerde karşılaşılan en önemli kısıtlar olan maliyet, süre, kapsam ve kalite açısından değerlendirmeleri yapılmıştır. Anket çalışması için sürdürülebilirlik ve YBM konularında deneyimli olan 26 kişiye ulaşılmıştır. Elde edilen sonuçlara göre farklı disiplinler arası birlikte çalışabilirlik, çoklu tasarım projelerinde birlikte çalışabilirlik, işletme kolaylığı, tasarımdaki değişikliğin tüm paftalara yansıması ve detay seviyesi belirleyebilme sürdürülebilir yeşil bina projelerinde YBM kullanımının en önemli avantajları olarak saptanmıştır. Bu noktada sürdürülebilir yeşil bina projelerinin geleneksel projelerle benzer sonuçlar gösterdiği söylenebilir. Bunun sebebi ise YBM kullanımının ana amaçlarından birisinin farklı disiplinleri aynı ortamda birleştirebilme kabiliyetidir. Ayrıca elde edilen sonuçlara göre, ankete katılan uzmanların tecrübelerine göre değişiklik bulunmaktadır. Görece daha tecrübeli katılımcılar, sürdürülebilir bina tasarım kolaylığı, tasarımdaki değişikliğin tüm paftalara yansıması, ve işletme ve yönetim kolaylığını; farklı disiplinler arası birlikte çalışabilirlik ile aynı derecede bir avantaj olarak görmektedir.

İkinci bölümdeki anket soruları analiz edildiğinde ise sürdürülebilir yeşil bina projelerinde YBM kullanımının fizibilite aşamasında kapsam, ihale ve sözleşme aşamasında kalite, tasarım aşamasında süre ve kapsam, inşaat aşamasında süre, ve işletme ve yönetim aşamasında maliyet özelinde, diğer kısıtlardan daha fazla avantaj getireceği hesaplanmıştır. $\mathrm{Bu}$ çıktılar sürdürülebilir yeşil bina projelerinde inşaat firmalarının YBM uygulamaları kullanma durumunda hangi aşamalarda hangi proje kısıtında ne ölçüde fayda sağlayacağını görebilmesi aşısından önemlidir. Örneğin, proje kapsamının önemli olduğu ve kapsam değişikliğinin sürekli yaşanabileceği karmaşık sürdürülebilir yeşil bina projelerinin fizibilite ve tasarım aşamalarında YBM kullanılması ciddi bir önem arz etmektedir. Kalitenin elzem olduğu kamu projelerinde ise en azından ihale ve sözleşme aşamasında YBM kullanımı ciddi bir avantaj sağlayacaktır.

YBM ve sürdürülebilirlik kavramları sürekli gelişen ve teknolojik gelişmelere bağlı olarak karmaşıklaşan süreç ve uygulamaları kapsar. Bu nedenle yapılan çalışma her ne kadar güncel literatür ve uzman görüşünü yansıtsa da gerçekleşen yeniliklerle birlikte benzer çalışmalar tekrar edilmelidir. Ayrıca bu çalışmada değinilen avantajların birbiri arasındaki ilişkisi hesaba katılmamıştır. Bu bağlamda daha etkin bir şekilde inceleme yapmak için yapısal eşitlik modeli (structural equation modelling) ya da analitik ağ süreci (analytical network process) gibi yöntemler kullanılabilir. Bu çalışmanın diğer bir kısıtı ise ankete katılan uzman sayısıdır. Her ne kadar ankete katılıma isteklilik ve ilgili konulardaki tecrübe hesaba katılarak analiz yapılmak istenmişse de, 26 uzman ile gerçekleştirilen anket sayısının artırılması çalışmanın güvenilirliğine katkı sağlayabilir. Son olarak ankete katılan uzmanların tamamı Türkiye'de çalışan uzmanlardan seçilmiştir. Dünyadaki tüm sürdürülebilir yeşil bina 
projeleri hakkında bilgi verebilmek için çeşitli ülkelerde çalışan uzmanların bilgilerinin derlenmesi gerekmektedir.

\section{Semboller}

$\alpha \quad$ : Cronbach's Alpha değeri

$A \quad$ : 1-5 likert ölçeğindeki en yüksek ağırlık

$N \quad$ : Katılımcı sayısı

$p \quad$ : Anlamlılık değeri

RII : Relative importance index (Göreceli önem indeksleri)

$W \quad$ : Katılımcılar tarafından verilen ağırlık

\section{Kaynaklar}

[1] İzoder, Dünyada Binalarda Enerji Verimliliği Stratejileri ve Türkiye'de Yapılması Gerekenler, 2010-2023 Isı Yalıtımı Planlama Raporu, 2010.

[2] YEGM, Bütünleşik Bina Tasarımı Yaklaşımı ile Proje Geliştirme Süreci Uygulama Kilavuzu, 2016.

[3] Ofluoğlu, S., BIM ve sürdürülebilirlik, in XVIII. Akademik Bilişim Konferansı, 2016, 1183-1187.

[4] Udomsap, A. D. and Hallinger, P., A bibliometric review of research on sustainable construction, 1994-2018, Journal of Cleaner Production, 254, 120073, 2020.

[5] Yeheyis, M., Hewage, K., Alam, M. S., Eskicioglu, C., and Sadiq, R., An overview of construction and demolition waste management in Canada: A lifecycle analysis approach to sustainability, Clean Technologies and Environmental Policy, 15 (1), 8191, 2013.

[6] Apanavičienè, R., Maliejus, K., and Fokaides, P., Sustainability Assessment of the Building Construction Stage Using Building Sustainability Assessment Schemes (BSAS), in IOP Conference Series: Earth and Environmental Science, 2020, 410, 012064.

[7] Eastman, C., Building Product Models: Computer Environments Supporting Design and Construction. Boca Raton: CRC Press, 1999.

[8] Ofluoğlu, S., Yapı Bilgi Modelleme : Gereksinim ve Birlikte Çalışabilirlik, Mimarist, $1-5,2014$.

[9] Reizgevičius, M., Ustinovičius, L., Cibulskieně, D., Kutut, V., and Nazarko, L., Promoting sustainability through investment in Building Information Modeling (BIM) technologies: A design company perspective, Sustainability (Switzerland), 10 (3), 2018. 
[10] Zhang, L., Chu, Z., and Song, H., Understanding the Relation between BIM Application Behavior and Sustainable Construction: A Case Study in China, Sustainability, 2019.

[11] $\mathrm{Wu}, \mathrm{W}$. and Issa, R. R. A., BIM execution planning in green building projects: LEED as a use case, Journal of Management in Engineering, 31 (1), A4014007, 2014.

[12] Seyis, S., Pros and Cons of Using Building Information Modeling in the AEC Industry, Journal of Construction Engineering and Management, 145 (8), 04019046, 2019.

[13] Wong, K. din and Fan, Q., Building information modelling (BIM) for sustainable building design, Facilities, 31 (3), 138-157, 2013.

[14] Ozorhon, B. and Karahan, U., Critical Success Factors of Building Information Modeling Implementation, Journal of Management in Engineering, 33 (3), 1-10, 2017.

[15] Ahn, Y. H., Kwak, Y. H., and Suk, S. J., Contractors' Transformation Strategies for Adopting Building Information Modeling, Journal of Management in Engineering, 32 (1), 05015005, 2016.

[16] Zuppa, D., Issa, R. R. A., and Suermann, P. C., BIM's impact on the success measures of construction projects, in Proceedings of the 2009 ASCE International Workshop on Computing in Civil Engineering, 2009, 346, 503-512.

[17] Kuiper, I. and Holzer, D., Rethinking the contractual context for Building Information Modelling (BIM) in the Australian built environment industry, Australasian Journal of Construction Economics and Building, 13 (4), 1-17, 2013.

[18] Demirdöğen, G. and Işık, Z., Structural Equation Model of the Factors Affecting Construction Industry Innovation Success, Teknik Dergi, 1-21, 2021.

[19] Taylor, J. E. and Bernstein, P. G., Paradigm Trajectories of Building Information Modeling Practice in Project Networks, Journal of Management in Engineering, 25 (2), 166-176, 2009.

[20] Shen, L. yin, Tam, V. W. Y., Tam, L., and Ji, Y. bo, Project feasibility study: the key to successful implementation of sustainable and socially responsible construction management practice, Journal of Cleaner Production, 18 (3), 254-259, 2010.

[21] Gurgun, A. P. and Arditi, D., Assessment of energy credits in LEED-certified buildings based on certification levels and project ownership, Buildings, 8 (2), 1-20, 2018.

[22] Uğur, L. O. and Leblebici, N., Investigation of the effects of energy and water saving benefits on property value in LEED certified green buildings, Teknik Dergi, 30 (1), 8753-8776, 2019.

[23] Fanning, B., Clevenger, C. M., Ozbek, M. E., and Mahmoud, H., Implementing BIM on infrastructure: Comparison of two bridge construction projects, Practice Periodical on Structural Design and Construction, 20 (4), 04014044, 2015.

[24] Azhar, S., Carlton, W. A., Olsen, D., and Ahmad, I., Building information modeling for sustainable design and LEED $₫$ rating analysis, Automation in Construction, 20 (2), 217-224, 2011. 
[25] Bynum, P., Issa, R. R. A., and Olbina, S., Building information modeling in support of sustainable design and construction, Journal of Construction Engineering and Management, 139 (1), 24-34, 2013.

[26] Hinze, J., Godfrey, R., and Sullivan, J., Integration of Construction Worker Safety and Health in Assessment of Sustainable Construction, Journal of Construction Engineering and Management, 139 (6), 594-600, 2013.

[27] Gurgun, A. P. and Koc, K., Contractor prequalification for green buildings - evidence from Turkey, Engineering, Construction and Architectural Management, 27 (6), 13771400, 2020.

[28] El-Sayegh, S. M., Manjikian, S., Ibrahim, A., Abouelyousr, A., and Jabbour, R., Risk identification and assessment in sustainable construction projects in the UAE, International Journal of Construction Management, 1-10, 2018.

[29] Atabay, S., Gurgun, A. P., and Koc, K., Incorporating BIM and Green Building in Engineering Education: Assessment of a School Building for LEED Certification, Practice Periodical on Structural Design and Construction, 25 (4), 04020040, 2020.

[30] Hosseini, M. R., Maghrebi, M., Akbarnezhad, A., Martek, I., and Arashpour, M., Analysis of Citation Networks in Building Information Modeling Research, Journal of Construction Engineering and Management, 144 (8), 04018064, 2018.

[31] Reeves, T., Olbina, S., and Issa, R. R. A., Guidelines for using building information modeling for energy analysis of buildings, Buildings, 5 (4), 1361-1388, 2015.

[32] Edwards, R. E., Lou, E., Bataw, A., Kamaruzzaman, S. N., and Johnson, C., Sustainability-led design: Feasibility of incorporating whole-life cycle energy assessment into BIM for refurbishment projects, Journal of Building Engineering, 24, $100697,2019$.

[33] Jalaei, F., Jalaei, F., and Mohammadi, S., An integrated BIM-LEED application to automate sustainable design assessment framework at the conceptual stage of building projects, Sustainable Cities and Society, 53, 101979, 2019.

[34] Carvalho, J. P., Bragança, L., and Mateus, R., Optimising building sustainability assessment using BIM, Automation in Construction, 102, 170-182, 2019.

[35] Ölçer B., İklim Krizinde BİM'in Üstleneceği Rol, Yapı Bilgi Modelleme, 2 (2), 19-29, 2019.

[36] Chong, H. Y., Lee, C. Y., and Wang, X., A mixed review of the adoption of Building Information Modelling (BIM) for sustainability, Journal of Cleaner Production, 142, 4114-4126, 2017.

[37] Olawumi, T. O. and Chan, D. W. M., An empirical survey of the perceived benefits of executing BIM and sustainability practices in the built environment, Construction Innovation, 19 (3), 321-342, 2019.

[38] Becerik-Gerber, B. and Kensek, K., Building information modeling in architecture, engineering, and construction: Emerging research directions and trends, Journal of Professional Issues in Engineering Education and Practice, 136 (3), 139-147, 2010. 
[39] Lu, Y., Wu, Z., Chang, R., and Li, Y., Automation in Construction Building Information Modeling (BIM) for green buildings: A critical review and future directions, Automation in Construction, 83 (June), 134-148, 2017.

[40] Marzouk, M. and Othman, A., Modeling the performance of sustainable sanitation systems using building information modeling, Journal of Cleaner Production, 141, 1400-1410, 2017.

[41] Li, B., Fu, F. F., Zhong, H., and B, L. H., Research on the computational model for carbon emissions in building construction stage based on BIM, Structural Survey, 30 (5), 411-425, 2012.

[42] Zhou, Y., Ding, L., Rao, Y., Luo, H., Medjdoub, B., and Zhong, H., Automation in Construction Formulating project-level building information modeling evaluation framework from the perspectives of organizations: A review, Automation in Construction, 81, 44-55, 2017.

[43] Bryde, D., Broquetas, M., and Volm, J. M., The project benefits of building information modelling (BIM), International Journal of Project Management, 31 (7), 971-980, 2013.

[44] Kivits, R. A. and Furneaux, C., BIM: Enabling sustainability and asset management through knowledge management, The Scientific World Journal, 2013, 1-14, 2013.

[45] Luth, G. P., Schorer, A., and Turkan, Y., Lessons from using BIM to increase designconstruction integration, Practice Periodical on Structural Design and Construction, 19 (1), 103-110, 2014.

[46] Ghaffarianhoseini, A. et al., Building Information Modelling (BIM) uptake: Clear benefits, understanding its implementation, risks and challenges, Renewable and Sustainable Energy Reviews, 75 (September 2016), 1046-1053, 2017.

[47] Olawumi, T. O. and Chan, D. W. M., Identifying and prioritizing the benefits of integrating BIM and sustainability practices in construction projects: A Delphi survey of international experts, Sustainable Cities and Society, 40, 16-27, 2018.

[48] Eadie, R., Browne, M., Odeyinka, H., McKeown, C., and McNiff, S., BIM implementation throughout the UK construction project lifecycle: An analysis, Automation in Construction, 36, 145-151, 2013.

[49] Azhar, S. and Brown, J., Bim for sustainability analyses, International Journal of Construction Education and Research, 5 (4), 276-292, 2009.

[50] Cheung, F. K. T., Rihan, J., Tah, J., Duce, D., and Kurul, E., Early stage multi-level cost estimation for schematic BIM models, Automation in Construction, 27, 67-77, 2012.

[51] Azhar, S., Khalfan, M., and Maqsood, T., Building information modeling (BIM): Now and beyond, Australasian Journal of Construction Economics and Building, 12 (4), 15$28,2012$.

[52] Ibrahim, M., Krawczyk, R., and Schipporeit, G., Two Approaches to BIM : A Comparative Study . ECAADe 2004 ECAADe 2004, Technology, 1-7, 2004. 
[53] Azhar, S., Building information modeling (BIM): Trends, benefits, risks, and challenges for the AEC industry, Leadership and Management in Engineering, 11 (3), 241-252, 2011.

[54] Parker, D. W., Parsons, N., and Isharyanto, F., Inclusion of strategic management theories to project management, International Journal of Managing Projects in Business, 8 (3), 552-573, 2015.

[55] Simms, C. and Rogers, B., The significance of flexibility in improving return on property investment: The UK perspective, Facilities, 24 (3-4), 106-119, 2006.

[56] Budayan, C., Analysis of critical success factors in public private partnership projects by triangulation method: Turkey perspective, Journal of the Faculty of Engineering and Architecture of Gazi University, 33 (3), 1029-1044, 2018.

[57] Chan, A. P. C., Darko, A., Olanipekun, A. O., and Ameyaw, E. E., Critical barriers to green building technologies adoption in developing countries: The case of Ghana, Journal of Cleaner Production, 172, 1067-1079, 2018.

[58] Martin, H., Vital, S., Ellis, L., and Obrien-Delpesh, C., Motivating Civil Engineering Students: Self-Determinacy Perspective, Journal of Professional Issues in Engineering Education and Practice, 144 (4), 04018005, 2018.

[59] Gündüz, M., Nielsen, Y., and Özdemir, M., Quantification of delay factors using the relative importance index method for construction projects in Turkey, Journal of Management in Engineering, 29 (2), 133-139, 2013.

[60] Eymen, U. E., SPSS 15.0 Veri Analiz Yöntemleri. İstatistik Merkezi Hakkında, 2007.

[61] Gunduz, M. and Elsherbeny, H. A., Operational Framework for Managing Construction-Contract Administration Practitioners ' Perspective through Modified Delphi Method, Journal of Construction Engineering and Management, 146 (3), $040191110,2020$.

[62] Ghasemi, A. and Zahediasl, S., Normality tests for statistical analysis: A guide for nonstatisticians, International Journal of Endocrinology and Metabolism, 10 (2), 486-489, 2012.

[63] Okudan, O., Budayan, C., and Dikmen, I., Development of a conceptual life cycle performance measurement system for build-operate-transfer (BOT) projects, Engineering, Construction and Architectural Management, 2020.

[64] Olawumi, T. O. and Chan, D. W. M., Identifying and prioritizing the bene fits of integrating BIM and sustainability practices in construction projects: A Delphi survey of international experts, Sustainable Cities and Society, 40, 16-27, 2018.

[65] Vidalakis, C., Abanda, F. H., and Oti, A. H., BIM adoption and implementation: focusing on SMEs, Construction Innovation, 20 (1), 128-147, 2020.

[66] Abotaleb, I. S., El-Adaway, I. H., Ibrahim, M. W., Hanna, A. S., and Russell, J. S., Causes, Early Warning Signs, and Impacts of Out-of-Sequence Construction: ExpertBased Survey Analysis, Journal of Management in Engineering, 35 (6), 04019030, 2019. 
[67] Gürcanli, G. E., Baradan, S., and Uzun, M., Risk perception of construction equipment operators on construction sites of Turkey, International Journal of Industrial Ergonomics, 46, 59-68, 2015.

[68] Larsen, J. K., Shen, G. Q., Lindhard, S. M., and Brunoe, T. D., Factors Affecting Schedule Delay, Cost Overrun, and Quality Level in Public Construction Projects, Journal of Management in Engineering, 32 (1), 04015032, 2016.

[69] Amini, A., Nikraz, N., and Fathizadeh, A., Identifying and evaluating the effective parameters in prioritization of urban roadway bridges for maintenance operations, Australian Journal of Civil Engineering, 14 (1), 23-34, 2016.

[70] Wood, G. D. and Ellis, R. C. T., Main contractor experiences of partnering relationships on UK construction projects, Construction Management and Economics, 23 (3), 317$325,2005$.

[71] Yurtcu, Ş. and Özocak, A., İnce Daneli Zeminlerde Sikişma Indisi’Nin Istatistiksel Ve Yapay Zeka Yöntemleri Ile Tahmin Edilmesi, Journal of the Faculty of Engineering and Architecture of Gazi University, 31 (3), 597-608, 2016.

[72] Jaafar, M., Abdul Aziz, A. R., Ramayah, T., and Saad, B., Integrating information technology in the construction industry: Technology readiness assessment of Malaysian contractors, International Journal of Project Management, 25 (2), 115-120, 2007.

[73] Gupta, M., Hasan, A., Jain, A. K., and Jha, K. N., Site Amenities and Workers' Welfare Factors Affecting Workforce Productivity in Indian Construction Projects, Journal of Construction Engineering and Management, 144 (11), 04018101, 2018.

[74] Baccarini, D., The concept of project complexity - A review, International Journal of Project Management, 14 (4), 201-204, 1996.

[75] Khalil, M. I. Al, Selecting the appropriate project delivery method using AHP, International Journal of Project Management, 20, 469-474, 2002.

[76] Tenah, K. A., Project Delivery Systems for Construction: An Overwiew, Cost Engineering, 43 (1), 30-36, 2001.

[77] Zhang, X., Win-win concession period determination methodology, Journal of Construction Engineering and Management, 135 (6), 550-558, 2009.

[78] Doumbouya, L., Gao, G., and Guan, C., Adoption of the Building Information Modeling (BIM) for Construction Project Effectiveness: The Review of BIM Benefits, American Journal of Civil Engineering and Architecture, 4 (3), 74-79, 2016.

[79] Awad, E. M. and Ghaziri, H. M., Knowledge Management. Upper Saddle River, NJ.: Pearson/Prentice-Hall, 2004.

[80] Field, A., Discovering statistics using IBM SPSS statistics, 5th ed. London: Sage Publications, 2009.

[81] Luong, D. L., Tran, D. H., and Nguyen, P. T., Optimizing multi-mode time-cost-quality trade-off of construction project using opposition multiple objective difference evolution, International Journal of Construction Management, 1-13, 2018. 
[82] Olbina, S. and Elliott, J. W., Contributing Project Characteristics and Realized Benefits of Successful BIM Implementation: A Comparison of Complex and Simple Buildings, Buildings, 9 (175), 1-19, 2019.

[83] Ilhan, B. and Yaman, H., Green building assessment tool (GBAT) for integrated BIMbased design decisions, Automation in Construction, 70, 26-37, 2016.

[84] Ilhan, B. and Yaman, H., BIM and sustainability concepts in construction projects: a case study, in SB13. Proceedings of Sustainable Procurement in Urban Regeneration and Renovation, 22-24 May (eProceedings), 2013. 